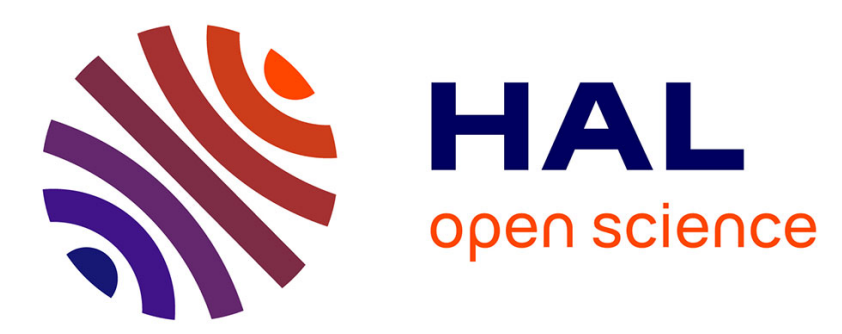

\title{
Non-invasive Raman analyses of Chinese huafalang and related porcelain wares. Searching for evidence for innovative pigment technologies
}

Philippe Colomban, Yizheng Zhang, Bing Zhao

\section{- To cite this version:}

Philippe Colomban, Yizheng Zhang, Bing Zhao. Non-invasive Raman analyses of Chinese huafalang and related porcelain wares. Searching for evidence for innovative pigment technologies. Ceramics International, 2017, 10.1016/j.ceramint.2017.06.063 . hal-01540320

\section{HAL Id: hal-01540320 \\ https: / hal.sorbonne-universite.fr/hal-01540320}

Submitted on 16 Jun 2017

HAL is a multi-disciplinary open access archive for the deposit and dissemination of scientific research documents, whether they are published or not. The documents may come from teaching and research institutions in France or abroad, or from public or private research centers.
L'archive ouverte pluridisciplinaire $\mathbf{H A L}$, est destinée au dépôt et à la diffusion de documents scientifiques de niveau recherche, publiés ou non, émanant des établissements d'enseignement et de recherche français ou étrangers, des laboratoires publics ou privés. 


\title{
Non-invasive Raman analyses of Chinese huafalang and related porcelain wares. Searching for evidence for innovative pigment technologies
}

\author{
Philippe Colomban, ${ }^{1} *$ Yizheng Zhang, ${ }^{1}$ Bing Zhao, ${ }^{2}$ \\ ${ }^{1}$ Sorbonne Universités, UPMC Univ. Paris 06, MONARIS UMR8233 CNRS, 4 Place Jussieu, 75005 Paris, \\ France
}

${ }^{2}$ CNRS, CNRS/EPHE/Collège de France/UPD07, CRCAO UMR8155, 52 rue du Cardinal Lemoine, 75005, Paris, France

*Corresponding author

Philippe.colomban@upmc.fr

\section{Abstract}

Eighteen Chinese painted enamelled porcelains and three Chinese enamelled Yixing stonewares dated to the $16^{\text {th }}$ to $19^{\text {th }}$ centuries and kept at the Musée national des arts asiatiques-Guimet (MNAAG), have been analysed with a mobile Raman set-up to identify their enamelling technology. Different Grand Feu (leadless or lead-poor colourless and blue enamel) and Petit Feu (lead-rich red (hematite), yellow and green ( $\mathrm{Pb}-\mathrm{Sn} / \mathrm{Sb} / \mathrm{X}$ pyrochlore) and black enamels) glazes were respectively identified on wares from the wucai group, the Famille verte group, and the huafalang group. Calcium phosphate was detected in a $17^{\text {th }}$ century vase as a rare opacifier. Cassiterite was identified in the light green glaze of an imperial huafalang bowl dated to the final period of the Kangxi reign (1662$1722), c a$. the $1^{\text {st }}$ quarter of the $18^{\text {th }}$ century. Lead arsenate was identified in the blue glaze of two artefacts, a huafalang bowl and a painted enamel water dropper, and in the blue enamel of a $19^{\text {th }}$ century Yixing teapot. Lead arsenate found in some of the blue enamels appears to arise from the arsenic content in Erzgebirge cobalt ores and not due to voluntary addition. This may prove the use of raw materials or enamel powder imported from Europe in developing these opaque colours. The use of lead arsenate as white opacifier is clear for a water dropper bearing the Yongzheng emperor's mark (r. 1723-1735). The technological palette appears different for the artefacts expected to originate from the same period and provenance (imperial workshop) which is consistent with a period of intense innovation, open to technological skill from abroad - i.e. from French/European painted enamel technology - as revealed by ancient French (Jesuits) and Chinese historical reports. Graphical abstract

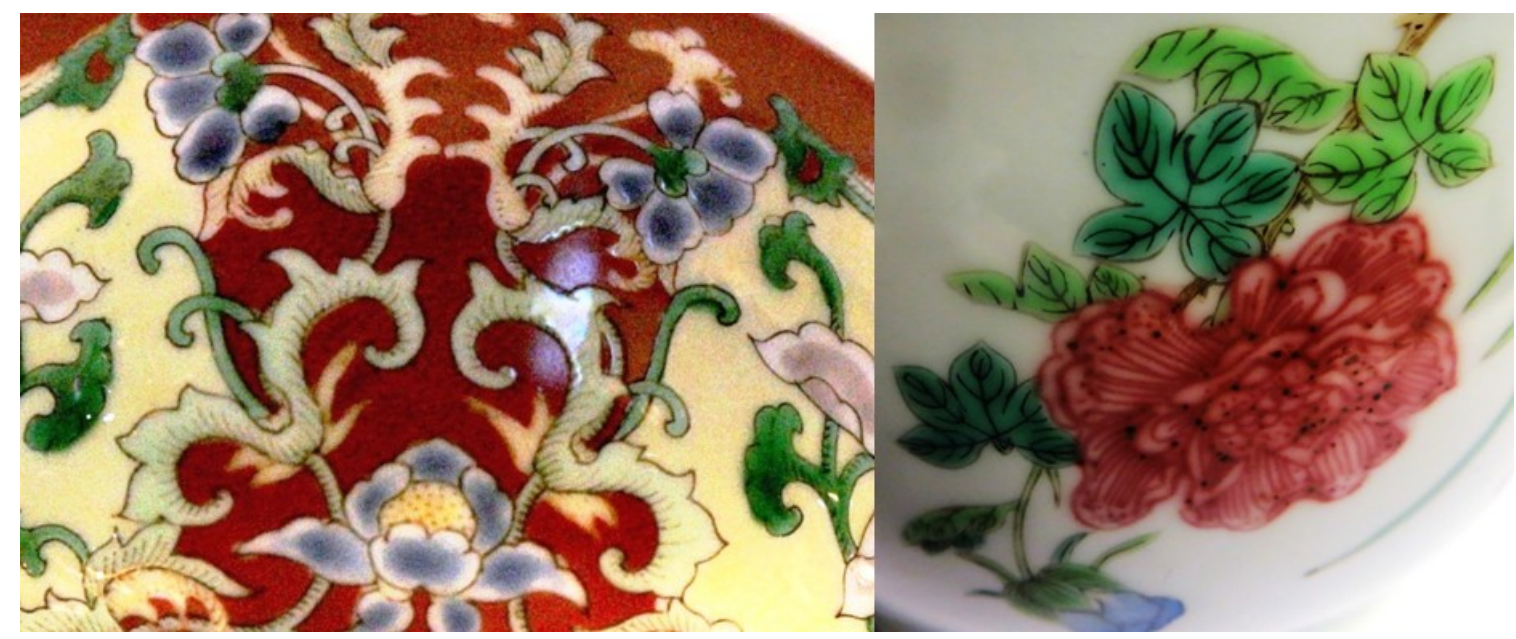


Keywords: B: impurities; B: spectroscopy; C: colour; D: glass arsenic

\section{Introduction}

For a long-time, Chinese porcelain had been essentially monochrome (e.g. celadons) or blue-andwhite (Qinghua) [1,2]. The pinnacle of this technology is the blue-and-white porcelain produced at Jingdezhen since 1320 at high firing temperature. From the 8th century onwards, enamelled stoneware follows a parallel but discontinuous development in China [1-4]. The joint venture of the underglaze and the overglaze technologies appeared to merge at Jingdezhen during the Chenghua reign (1465-1487) of the Ming Dynasty. This new technique is named in Chinese as doucai (colours filled within underglaze blue outlines). Multi-colour enamelled porcelains thus produced through the Ming Dynasty are denominated in Chinese with the term wucai (five colours). Both doucai and wucai colorations are a combination of under- and over-glaze décors. The culmination of these techniques was succeeded during the Qing Dynasty (1664-1912) with the vivid colour palette of Famille verte group and Famille rose group [5,6]. Despite the great interest of many scholars on Chinese ceramics from the stylistic approach, the number of analytical studies devoted to Chinese enamelled wares is rather limited and concerns mainly on monochrome [1,7-12] and blue-and-white porcelains [13-19]. Furthermore most of the studies are recent except the pioneer works of Zhang [5], Kingery and Vandiver [6] and then of Wood [1].

Regarding porcelain technology, the underglazed décor is drawn on a porous (generally unfired or incompletely sintered) body with an aqueous mixture containing the colouring agents/precursors that allows the depictions made of rather sharp border lines with pre-assigned coloured areas. On the contrary, the overglaze painting within the areas should be made on an already glazed (i.e. nonporous) substrate using a viscous oil-based mixture that makes the drawings less sharp. Furthermore it is difficult to make sharp applications since temperature will diffuse and oxidize small colouring ions and degrade large pigments. The achievement of a sharp delimitation between coloured glazed areas is thus a difficult task (Fig. 1) where, the low viscosity of the glaze at the top firing temperature and the fast diffusion of colouring ions tend to spread out the colours. For working out these difficulties, there exist several possibilities: the first solution is to use pigments in the place of ions as colouring agents (the later so-called 'couleurs transparentes' technique) [20]; the second one is the application of a physical wall, such as a spinel- or chromite-based refractory line delimiting the coloured areas and hindering the diffusion of ions, as first made by Samarkand and Iznik potters (ca. 1500 [21]), or the use of a thin metal foil as inlay (cloisonné) when the substrate is a metal body [2224]. The use of very viscous rue oil to mix with the colour components for painting and firing with 
lower temperature minimizes some of the above mentioned issues. Thus, enamelled décors with well-defined border lines between coloured areas is called 'cloisonné painted' or 'painted' enamel. The overglazing of an already glazed item requires the use of a glaze composition with a melting temperature about fifty/hundred, or more, ${ }^{\circ} \mathrm{C}$ less than that of the glaze substrate temperature, which obviously means many firing cycles for complex décors. The type of the glaze fired with the porcelain body is a potash-lime aluminosilicate that melts at about $1300^{\circ} \mathrm{C}$ or more $[1,25,26]$. The overglaze should thus melt below $\sim 150^{\circ} \mathrm{C}$, or less. Lead-based glazes usually liquefy at temperatures below $1000^{\circ} \mathrm{C}$ and were commonly used in China since the Han Dynasty (ca > 221) [1]. Overglaze polychrome wares coloured with copper green, iron red, antimony-iron yellow, and iron-manganese lead-glazes were produced subsequently from the $8^{\text {th }}$ century onwards $[1,5,6,27-29]$.

New productions appeared during the Kangxi reign of the Qing Dynasty, the so-called Famille verte (belonging to wucai group) and Famille rose (called fencai ('powder colours') or ruan cai ('soft colours') in Chinese) and the falangcai or enamel colour ware [4,30-34]). Falang might be the homonym of the Chinese character meaning France at that time. For some scholars, this technique can be described as being used to imitate the European painted enamels and ascribed as being introduced by French and Italian Jesuits established since in the later $17^{\text {th }}$ century at the Manchu Court [2,35-40]. Fathers J.F. Gerbillon (1654-1707, Chinese name Zhang Chen) and J. Bouvet (16561730, Bai Jin) developed a chemistry workshop for the Kangxi emperor in the Palace, while J. Gravereau (1690-1762, Chen Zhongxing ), F.J. Castiglione (1688-1766, Italian, Lang Shining) and P.M. Grimaldi (1618-1686, Italian, Min Mingwo) were requested to work on painted enamel décor. It was also reported that a learned representative of Louis XIV King, F. de Fontaney (1643-1710, Hong Ruohan) came to the Manchu Court in 1687 with presents of enamelled wares, which led to the importation of pigments and colouring agents from France. A German expert (K. Stumpf) also contributed to establish the Imperial Glass Workshop.

A major characteristic of this 'new' enamelled artefacts was the use of opaque lead-based overglazes (Table 1), especially for the blue, yellow, and white colours [1,2,4-6,30-34]. The opaque white enamel is called bo li bai (glassy white) in Chinese. Green- and rose-colored enamels were named as yangcai, i.e. 'foreign colour' $[4,32,33]$, where the green was obtained by copper ions and the rose by colloidal gold ("purple of Cassius"). One important characteristic of these new colours was their opacity, and their capacity to mix, alone or together, with white to form a large variety of shades $[2,6]$. The white pigment was described as tin oxide [33] but also as an arsenic-based compound (see Table S2 Supplementary Materials) [5], and yellow was based on lead antimonate [5,31,34]. A description of the pigments and enamel preparation methods was reported by Père d'Entrecolles in his 1712 and 
1722 letters [36] and then tested in 1900 by G. Vogt, the famous technical director of the French Sèvres Manufacture [41]. The objective of Chinese potters was to achieve objects decorated with a palette rather like the one achieved with oil painting, while the use of 'couleurs transparentes' in the previous wucai productions which produced décors more similar to water colours. The origin of the cloisonné colour technique was questioned by N. Wood [1] who claimed that the new opaque colours could well have been borrowed from the current Chinese cloisonné on metal technology and not imported from Europe. However, it should be noted that the technique of colour achievement regarding cloisonné enamel on metal is different from that of the painted enamel on porcelain where the glaze ranges typically between $20 \mu \mathrm{m}$ (thin overglaze) to $300 \mu \mathrm{m}$ (glaze), much lower values that those of metal enamels (up to a few mm). As noted by Kingery and Vandiver in 1986, 'the descriptions of the enamel technology are completely speculative' [6].

Painted falang porcelain (huafalang in Chinese) wares were produced in limited quantity from the end of the Kangxi reign, both in the Palace workshops located inside the Palace and in the Imperial Manufacture of Jingdezhen. Consequently, the relevant artefacts are very rare and kept in the secure areas of the museums (Fig. 1), making reliable data concerning the glaze, colouring agents, and body characteristics even rarer and inaccessible $[1,5,6,30,31]$.

The effectiveness of Raman spectroscopy as a non-invasive technique, especially by the mean of mobile set-up, for the identification of pigments, opacifiers, and glaze composition is now well established [13,18,20-23,25,26,31,42-48]. We report here the analysis of 21 Chinese artefacts belonging to the Paris Musée national des arts asiatiques - Guimet (MNAAG) Collection, from the end of the $16^{\text {th }}$ to the $19^{\text {th }}$ century. Some of these artefacts can be attributed to the imperial productions, whiles others to the private workshops (Table 1). One item of the Famille verte appears fairly to be a porcelain copy (G 4551) of a Limoges enamelled metal cup, assigned to be made in a private workshop $[49,50]$. Our first objective is the identification of the enamelling technology used in the production of wucai, doucai and huafalang wares to understand about the technological transition between the two productions. The search of lead arsenate (as opacifiers), lead stannate/antimonate pyrochlore solid solutions, also called Naples Yellow (as yellow pigments) and $\mathrm{Au}^{\circ}$ nanoparticles (Cassius purple, as the pink colouring agent) appear as the most efficient way to identify artefacts made with unconventional technologies, in particularly those developed with possible imported huafalang materials. In these regards, Raman scattering has proven its efficiency to identify these colouring agents in many similar types of artefacts [20-23,31,43-46]. The following up study will be to perform precise in-depth Raman analysis from the glazed up- surface to the glazebody interface and XRF analysis with portable instruments on identified objects in order to identify 
the impurities, which are characteristic of the origin of different colouring agents and the glaze stratigraphy.

\section{Experimental}

Technique: Raman spectra were recorded with the HE532 Horiba Jobin-Yvon mobile spectrometer equipped with a $532 \mathrm{~nm} 300 \mathrm{~mW}$ Ventus Quantum laser, an x200 Mitutoyo and an x50 Nikon microscope long working distance objectives, as previously described [20-22]. The laser and the spectrometer are fibre optically connected to the remote Superhead ${ }^{\circledR}$ put on a heavy and very stable stage with XYZ micrometric displacements (Fig. 1b). The $x 50$ objective that probes a $\sim 4 \times 4 \times 12 \mu \mathrm{m}^{3}$ volume is first used. A much small laser spot obtained with the $x 200$ objective (about $0.5 \times 0.5 \times 2 \mu \mathrm{m}^{3}$ ) requires a very precise focus (a lengthy process) but guaranties the single glaze layer analysis and generally gives a much better spectrum with less background. The height position of the artefact is adjusted with the use of reams of copy paper as support. Finally, an opaque black fabric is put on the object and the remote head to prevent the ambient light and protect the scientist's eyes from the laser scattering. The focus is controlled by first maximising the intensity of the collected fluorescence/background signal and then of the pigment/glaze one. The laser power at the sample ranges between a few $\mathrm{mW}$ for dark coloured areas (black, red) to about $10 \mathrm{~mW}$ for light coloured areas (white, yellow). Recording times range between a few seconds and a few minutes. More than 250 spots were analyzed and about 230 of them were successfully recorded (see Supplementary Materials).

Artefacts: Figure 2 and Table 1 show the different groups of the analyzed artefacts among the selected objects. The best characteristic ones are given in Fig. 1. The photography of each studied artefact with the position of the analyzed spots is given in the Supplementary Materials. At first, three rare bowls attributed to the Imperial productions and made during the first quarter of the $18^{\text {th }}$ century or between 1723 and 1735 were analysed. A wucai plate, a water dropper, and a tea cup from the same period, exhibiting the highest quality of imperial production were selected for comparison. Six other wucai artefacts from earlier periods (end of $17^{\text {th }}$ to beginning of $18^{\text {th }}$ century) and four $18^{\text {th }}$ century artefacts assigned to private kiln productions were also analysed as well as three zisha Yixing enamelled red stoneware artefacts ( 2 teapots and 1 bowl). Finally, a cup with European shape and design ( $18^{\text {th }}$ C., Fig. 1) and a "Kangxi" emperor sealed artefact were analysed.

\section{Results and discussion}




\subsection{Raman signatures}

Figs 3 to 6 show the representative Raman spectra recorded during the measurements. Additional spectra are presented in Figs S1 \& S2. Main peak wave numbers and assignments are given in Table S1. We will first present and discuss the Raman signature of the glaze and then those of the pigments/opacifiers. Artefacts will be considered chronologically.

Glazes: According to previous studies on hard paste $[20,25,26,46,51,52]$ and soft paste porcelain $[45,46,51]$, the differentiation of Grand Feu (i.e. a glaze fired at high temperature with the body) and Petit Feu (i.e. an overglaze deposited on the already fired porcelain/stoneware and hence heated at a lower temperature in a second or third thermal treatment) is obtainable by Raman scattering. The Raman signature of silicate glass presents two main broad bands: the contribution of the $\mathrm{SiO}_{4}$ tetrahedron bending and stretching modes at $\sim 550 \mathrm{~cm}^{-1}$ and $\sim 1000 \mathrm{~cm}^{-1}$ respectively [42-44,52]. The centre of gravity of the later mode shifts with the flux content in the glass composition [42]. The area ratio of the bending to stretching mode decreases with the polymerisation and melting temperature [52-55]. For instance, in Fig. 3, the spectrum of the colourless glaze of $G 5687$ vase exhibits a rather strong band at $495 \mathrm{~cm}^{-1}$ and a weaker one at $1060 \mathrm{~cm}^{-1}$, a signature characteristic of a Grand Feu KCa silicate glass ((in agreement with literature, Table S2), which is used for hard-paste porcelain $[25,26,51]$. On the contrary, the spectra collected for yellow and green glazes (G 4374, G 5687 and MG 5806) show a stronger bump at ca. $980 \mathrm{~cm}^{-1}$ and a much weaker one at $480 \mathrm{~cm}^{-1}$, characteristic of a lead-rich glaze [42], which is very similar to that used for soft-paste porcelain $[45,46,51]$. Band shape and centre of gravity display a slight shift depending on the exact composition of the glaze due to the possible reaction with the pigments and the partial dissolution of the (glaze or body) substrate (Note, due to the reaction between the lead-rich overglaze and the potash-base glaze, the composition shift from surface to the body. Due to the high volatility of $\mathrm{PbO}$, the composition of the overglaze is different from that of the precursor !). This could also be due to the different position of the focus of the objective in between the glaze surface and the glaze/body interface. Thus, a detailed in-depth Raman profile is usually needed to draw precisely the stratigraphy. Hence, the centre of gravity of $\mathrm{SiO}_{4}$ stretching band lowers for the yellow and green glazes because of the use of lead-rich pigments (see further) that increase the lead content, locally. On the contrary, those of the blue spots are very similar to that of the Grand Feu glaze since the blue décor of wucai ware was drawn under the glaze (e.g. Fig. 4, G 5250 \& Fig. 5, G 3361). The relative intensity of the different components of the $\mathrm{SiO}_{4}$ stretching envelope changes with the relative proportion of the more or less connected tetrahedron (isolated, connected with 1, 2 or 3 shared oxygen of fully connected $[42,53-$ $55])$, i.e. with the respective composition. For instance, the spectrum of the blue glaze (5806) shows three main components at ca. 905,970 and $1030 \mathrm{~cm}^{-1}$, indicating a more connected silicate network 
with a higher melting temperature than those of yellow and green glazes, which only have two main components at ca. 905 and $990 \mathrm{~cm}^{-1}$.

Four types of glazes can be identified: a high temperature 'Grand Feu' porcelain glaze with

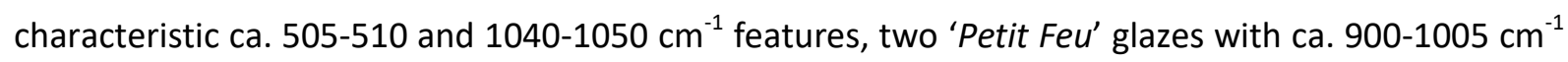
or $900-980 \mathrm{~cm}^{-1}$ doublets, and a glaze displaying an intermediate signature with c.a. 905, 970 and $1030 \mathrm{~cm}^{-1}$ triplet.

It is noteworthy that that the narrow and strong $463 \mathrm{~cm}^{-1}$ peak which is characteristic of $\alpha$ - quartz unreacted grains $[20,45,51]$ is commonly observed both in the paste and glaze signatures in our artefacts, as usual for porcelain.

Pigments: Specific pigment signatures have been obtained for red, yellow, green, blue, black and some of the white or lightened shades. Alternatively, Raman spectra lack any specific signatures in the studied spectral range when the colouring agents used are ions dissolved or metal nanoparticles dispersed in the silicate network. In the first case, the Raman spectrum is that of the colourless glaze (e.g. for blue glass coloured with $\mathrm{Co}^{2+}$ ions); in the second case, no spectrum is generally obtained due to the huge absorption of metal nanoparticles. In rare cases, only the Raman spectrum of the second minor phases can be observed, e.g. for rose/purple glaze.

Red: The red glaze pigment is identified as hematite, having characteristic resonance component at ca 1310-1315 $\mathrm{cm}^{-1}$ and 223-290-405 $\mathrm{cm}^{-1}$ triplet [20,56], (Fig. 3 (G 4374, G 5687 \& 5806), Fig. 4 (G 913 \& G 4806), Fig. 5 (G 822, G 5615, MG 7368 \& G 5068) and Figs S1 (G 421) and S2 (G 5696, G 1351 \& G 5609, Supplementary Materials). Furthermore, small differences can be noted as the variable intensity of the $245 \mathrm{~cm}^{-1}$ band or slight broadening of the bands. The latter case is characteristic of the partial substitution of Fe atoms by Ti or other element, as observed when raw materials are used, such as the bengara earth, from Bengal, used in ancient Japanese wares [56]. These variations indicate that different raw materials had been used. On the other hand, the variable intensity of the $660 \mathrm{~cm}^{-1}$ component, characteristic of a hematite $\left(\mathrm{Fe}_{2} \mathrm{O}_{3}\right)$-magnetite $\left(\mathrm{Fe}_{3} \mathrm{O}_{4}\right)$ mixture depends on the reducing firing conditions that promote the magnetite phase. Partial substitution with elements such as chromium could also promote the formation of the spinel structure. Precise XRF measurements are needed to better characterize these different metal features.

Yellow and green: Yellow and green colours are discussed together since these colours are often obtained by dispersion of yellow pigment in a glass matrix coloured with $\mathrm{Co}^{2+}$ ions $\left.[20,43,44,46,57]\right)$. The yellow pigment of the porcelain glazes was found to be a lead-based pyrochlore solid solution, an old pigment often used since the Byzantine period in Europe and appeared three millennia ago in 
Egypt [58]. The end members are $\mathrm{Pb}_{2} \mathrm{SnO}_{4}$ (Lead tin yellow Type I) and $\mathrm{PbSb}_{2} \mathrm{O}_{7}$ but $\mathrm{Sn}$ and $\mathrm{Sb}$ ions can be partially substituted by many other elements such as Si (Naples Yellow Type II), Fe and Zn [5763]. Furthermore, colour changes with oxygen deficiency under the reducing atmosphere. The stronger mode ranging between ca. 125 and $145 \mathrm{~cm}^{-1}$ is easily detected because it corresponds to the collective motion of $\mathrm{Pb}^{2+}$ ions (its huge intensity arise from the high ion polarisability due to the high number of electrons involved in the $\mathrm{Pb}-\mathrm{O}$ bond). Because of the high mass contrast between $\mathrm{Pb}$ and other elements, this mode is not directly related to the $\mathrm{Sb}, \mathrm{Sn}$, Fe or Si substitution and highly depends on the synthesis parameters (i.e., firing temperature and oxygen stoichiometry). On the contrary, the internal modes between ca. 300 and $510 \mathrm{~cm}^{-1}$ are more sensitive to the other elements, for instance the $455 \mathrm{~cm}^{-1}$ one to $\mathrm{Sn}$, the ca. $325-330$ to Sb and the $508 \mathrm{~cm}^{-1}$ one characteristic of the mixed compositions. Pure $\mathrm{Pb}_{2} \mathrm{SnO}_{4}$ compound exhibits the $\sim 195-200 \mathrm{~cm}^{-1}$ peak. Pyrochlore yellow pigments were detected in the $17^{\text {th }}$ century wucai glaze (Fig. 3 ) but the low intensity of the signature makes it difficult to suggest how these elements were incorporated in the lead-based composition. This may indicate that the pigment quantity used is small, likely due to the novelty/rareness of this pigment. On the contrary, the very good spectrum recorded on G 5250 falangcai bowl (Fig. 4) indicates the use of a high-quality $\mathrm{Sb} / \mathrm{Sn}$ mixed pigment, which could have been imported. A rather intense spectrum has also been collected on $G 5068$, the $18^{\text {th }}$ century vase. The signature is consistent with a Sn-rich pyrochlore composition (Fig. 5). On the contrary, the spectra collected on the Yixing teapots, MG 3668 and MG 9604, are consistent with Sb-based Naples yellow pyrochlore composition (Fig. 6). The variety of pyrochlore signatures is indicative of different origins (workshop) and/or times of production.

Black: A homogeneous black colour is difficult to achieve in a complex décor [64] since the production of pieces such as the G 1710 vase (Fig. 2) had not been possible before the Qing Dynasty. Two types of signatures were recorded:

-i) a mixture of amorphous carbon (1355-1575 $\mathrm{cm}^{-1}$ doublet) [65]; this indicates that the firing was conducted under reducing conditions, as required to keep a white body [66] and/or that an organic medium or carbon powder was added, and

- ii) spinel(s) (645 to $685 \mathrm{~cm}^{-1}$ peak [67], e.g. in G 5687, MG 5806 (17 $7^{\text {th }}$ century, Fig. 3), MG 9604 (Yixing, $18^{\text {th }}$ century, Fig. 6$)$ and $G 5609$ objects $\left(19^{\text {th }}-20^{\text {th }}\right.$ centuries, Fig. S2). Also, there is manganese oxide(s) with a 550-595 $\mathrm{cm}^{-1}$ doublet, e.g. in G $4374\left(16^{\text {th }}-17^{\text {th }}\right.$ century, Fig. 3), G 913 (huafalang ware, $18^{\text {th }}$ century, Fig. 4), G 822, G 3361 (18 ${ }^{\text {th }}$ century ware, Fig. 5), MG 3668 (Yixing ware, $18^{\text {th }}$ century, Fig. 6) and G 5609 (19 $19^{\text {th }}-20^{\text {th }}$ century, Fig. S2). It is difficult to determine the phase type since the huge sensitivity of manganese oxides to laser illumination may artificially induce phase transition or transformation when high power illumination was required in the on-site measurements. 
Blue: Blue colour is usually obtained by the dissolution of $\mathrm{Co}^{2+}$ ions in the amorphous silicate network [3]. When the ion concentration exceeds a few wt\% (locally), olivine silicate $\left(\mathrm{CO}_{2} \mathrm{SiO}_{4}\right)$ or cobalt aluminate spinel $\left(\mathrm{CoAl}_{2} \mathrm{O}_{4}\right)$ precipitates out $[45,46]$, in both lead-based (soft paste) or silica-rich (hard paste) glazes respectively. The olivine Raman signature has doublet at about $825 \mathrm{~cm}^{-1}$ [68].

Opacifiers: Three types of white pigments were identified. Cassiterite (tin oxide- $\mathrm{SnO}_{2}$ ), with a characteristic doublet at 635 and $775 \mathrm{~cm}^{-1}$ [69-71], was detected in light green areas of the huafalang G5250 ware (Fig. 4). Cassiterite, an innovative opacifier of the Late Roman period ( $5^{\text {th }}$ Century [69]), largely was used by Islamic potters to produce terra cotta and faience with a complex decoration [46, 70-72], as well as by European porcelain arcanists [45,46]. A peak at $955 \mathrm{~cm}^{-1}$, consistent with the calcium phosphate $\left(\mathrm{Ca}_{3}\left(\mathrm{PO}_{4}\right)_{2}\right)$ signature, was noted in the yellow area of the $\mathrm{G} 568717^{\text {th }}$ century vase (Fig. 3). It is considered that calcium phosphate $\left(955 \mathrm{~cm}^{-1}\right.$ peak) is a rather rare glaze opacifier. First used in late antique glass mosaic tessarae [73], it was used in rare Islamic glass [57] as the alternative opacifier of lattimo glass at the end of the $16^{\text {th }}$ century $[57,74,75]$ as well as that of Medici porcelain glaze [74]. Bone ash was added to the glaze mixture to obtain the precipitation of calcium phosphate. Since some potassium rich glass may also exhibit a component at $\sim 960 \mathrm{~cm}^{-1}$ [42], additional Raman and XRF measurements are needed for a definitive assignment. Lattimo Venetian glass was found to be opacified with lead arsenate [57]. The Raman signature of lead arsenate is very strong because the high number of electrons involved in the As-O bond. This peak is observed between 810 and $830 \mathrm{~cm}^{-1}[67,76]$ in many coloured areas, in blue huafalang G 5250 (Fig. 4) and G 3361 (Fig. 5) among the $18^{\text {th }}$ century wares. In the later paint brush pot, lead arsenate was also detected in the white and purple areas. Intense signatures were also obtained on enamelled Yixing wares (Fig. 6). Recently, elemental composition analysis suggested the association of (European) cobalt and arsenic in the blue décor of some Famille rose porcelains [78]. The different wave numbers could indicate different compositions of $\mathrm{Pb}$-Ca solid solution [79]. For vivid blue-coloured enamels, the superimposition of the olivine $\mathrm{Co}_{2} \mathrm{SiO}_{4}$ contribution (ca. $825 \mathrm{~cm}^{-1}$ doublet) could also shift the maximum. But, when peak intensity is maximal in the white area, the assignment to lead arsenate is certain. The highest signal recorded on Yixing wares is consistent with the use of higher amount of pigment or of a more advanced preparation technology. It should also be noted that very similar arsenate Raman signatures were observed on the blue décor of some Medici, Saint-Cloud, Chantilly, Mennecy, Sceaux and Vincennes soft paste porcelains $[45,46]$, in an English soft-paste ("Bone China") porcelain blue plaque made ca 1730 [80] as well as in Capo di Monte production [81], in agreement with the use of European cobalt ores. 


\section{Conclusions}

This preliminary non-invasive on-site Raman investigation of selected wucai , doucai and huafalang artefacts confirms that lead arsenate was used for some huafalang objects attributed to the Imperial productions as reported by F. Zhang [5]. However, lead arsenate was not detected in all artefacts attributed to the same imperial workshop, although arsenates are very strong Raman scatterers. It is important to note that in these later artefacts (Table 1), the blue glaze composition contains less PbO than in other colours. It could be due to a reaction between the lead-based overglaze and the porcelain glaze or even the body or due to the use of an intermediate special composition. The more reasonable assumption may be that arsenic arises from the cobalt ores $[45,46,80,81]$. Eighteen century European porcelains made with European cobalt ores exhibit the same Raman signature as shown in refs $[45,46,77,80,81]$, but also in some Limoges enamels [82] and glass beads [83-85] produced during the $17^{\text {th }}$ and $18^{\text {th }}$ century. The cobalt ores come from Erzgebirge mountains between Saxony and Bohemia and contain a high level of arsenic (As/Co 0.1-0.2) [83-86], which may explain the formation of lead arsenate in the blue enamel. The ratio As/Co had reached $\sim 0.4$ during the $17^{\text {th }}$ century [85]. On the contrary, Asian cobalt ores used during Ming dynasty in China and Vietnam do not contain arsenic but instead a high level of manganese, and iron [25,26,86-89]. This is a significant proof of the use of either imported cobalt ore or prepared blue enamel imported from Europe. White opacifier, namely calcium phosphate seems to be present in a $17^{\text {th }}$ century vase and cassiterite, as reported by Garner [33], was also detected in the light green enamel of the Kangxi huafalang $\mathrm{G} 5250$ bowl in association with the pyrochlore yellow colour. This could also indicate the use of imported materials ( $\mathrm{CaF}_{2}$ is used to opacify white cloisonné enamels [22]). Note that arsenicpoor and arsenic-poor cobalt was simultaneously used in France, as demonstrated for Limoges enamels produced at the end of $17^{\text {th }}$ and beginning of the $18^{\text {th }}$ century [82]. Consequently, the nondetection of arsenate signature in blue décor cannot exclude to the use of European arsenate-free cobalt (as in some Limoges enamels [82]) and measurement of associated traces is needed to discuss its provenance [90].

Voluntary use of lead arsenate white opacifier was identified in white areas of the G 3361 water dropper as well in the later Yixing productions (MG 3668, MG 9604 and MG 8062). The very strong arsenate Raman signature is consistent with a great mastery of the manufacture of the arsenic-based enamel. Lead pyrochlore Sb-Sn (Naples Yellow type) was also detected but was already observed in the $16^{\text {th }}$ and $17^{\text {th }}$ centuries wares (Fig. 3) and appears not very characteristic of the innovation here. Therefore, the study of more artefacts is required to obtain a more definitive conclusion. Recently, arsenate was detected in Famille Rose porcelain shards $[77,78]$ in agreement with previous work of Zhang [5]. Identification of the minor and trace elements associated to the above mentioned 
colouring phases are needed to better discuss the provenance of the raw materials. Alternatively, a precise in-depth (non-invasive) Raman micro-spectrometry of the above mentioned artefacts, or the availability of shards, is required to provide a 3D view of the stratigraphy of the glassy layers forming the glaze décor. The Raman technique failed to identify the colouring ions that don't form complexes or crystallites. Diffuse reflectance spectroscopy $[89,91]$, portable XRF $[91,92]$ or Synchrotron $\mu \mathrm{XRF} /$ diffraction [93] should be also very useful.

\section{Acknowledgments}

The authors thank Mrs S. Makariou, President of the musée national des arts asiatiques-Guimet for the permission to study masterpieces of the MNAAG Collection and for her kind support. Mrs C. Deléry, and H.-C. Tsao, Curators as well as V. Guillaud and the entire keeper' staff are acknowledged for their contribution to the work. The authors thank Drs G. Wang, Y. Lei, W. Ren and F. Guo for discussions. French-China Cai Yuanpei 36685RB cooperative program and HORIBA Scientific JobinYvon Company are kindly acknowledged for partial support. This work has been made in the framework of the CNRS-Palace Museum of Beijing LIA (Laboratoire international associé) production (La circulation des objets émaillés entre la France et la Chine (milieu XVII ${ }^{e}$ - milieu XIX siècle): Interactions technologiques, culturelles et diplomatiques). 


\section{Références}

1. N. Wood, Chinese Glazes: their origins, chemistry and recreation, A \& C Black, 1999, London.

2. F. Lili, La céramique chinoise, China Intercontinental Press, Beijing, 2011.

3. Shenzhen bowuguan, Shenzhen Wangye bowuguan, Shenzhen shi wenwu guanli bangongshi, Shenzhen shi wenwu jiandingsuo, The Deities and Secular World in Polychrome Overglaze Decoration Ceramics of Kin and Yuan Dynasties, Beijing, Wenwu Chubanshe, 2009.

4. C. Shih, Y. Peng, On the Origin and Development of Three Terms for Qing Dynasty Overglazed Enamels: Falangcai (珐琅彩), Yangcai (洋彩) and Fencai (粉彩), National Palace Museum Research Quarterly, 29[4] (2012) 1-47.

5. F. Zhang, The origin and development of traditional Chinese glazes and decorative ceramic colors, in Ancient Technology to Modern Science, vol. 1, Ceramics and Civilizations Serie, W.D. Kingery, vol. 1, The American Ceramic Society, Colombus, 1985, p. 163-179.

6. W.D. Kingery, P.B. Vandiver, The eighteenth-century change in technology and style from the Famille-Verte palette to the Famille-Rose Palette, in Technology and Style, Vol. 2, Ceramics and Civilization Serie, W.D. Kingery Ed., The American Ceramic Society, Colombus, 1986, p. 363-381.

7. S.L. Feng, X.Q Feng, J.H. Zhu, G.X. Xie, L.T. Yan, L. Li, G. Li, Q.H. Shen, Nondestructive analysis on ancient porcelain of Longquan Kiln in Zhejiang Province by WDXRF, Chinese Physics C 32 (2008) 284-288.

8. L. Li, S.L. Feng, X.Q. Feng, Q. Xu, L.T. Yan, B. Ma, H. Huo, Study on the chemical composition features of Longquan celadon excavated from the Chuzhou site of Huai'an City in Jiangsu province by EDXRF, Chinese Physics C 35[7] (2011) 689-694.

9. T.Q. Zhu, H. Huang, H.M. Wong, L.M. Hu, X.B. Yi, Comparison of celadon from the Yaozhou and Xicun kilns in the Northern Song Dynasty of China by X-ray fluorescence and microscopy, J. Archaeological Sci. 38[11] (2011) 3134-3140.

10. J. Wu, M.L. Zhang, T.J. Hou, Q.J. Li, J.M. Wu, Analysis of the celadon of the Tang and the Five Dynasties unearthed from Nan Kiln and Lantian Kiln site of Jingdezhen, China, Ceramics Int. 41[5] (2015) 6851-6857.

11. M.H. He, Y.F. Xiao, S.D. Zhang, R. Liu, W. Hong, B.L. Huang, Composition analysis of ancient celadon via femtosecond laser ionization time-of-flight mass spectrometry, Appl. Surf. Sci. 351 (2015) 624-634.

12. E.T. Hall, A.M. Pollard, Analysis of Chinese monochrome glazes by X-ray Fluorescence spectroscopy, Proc. Intern. Conference Chinese Pottery \& Porcelain, 1985. 
13. L.D. Kock, D. de Waal, Raman studies of the underglaze blue pigment on ceramic artefacts of the Ming dynasty and of unknown origins, J. Raman Spectrosc. 38[11] (2007) 1480-1487.

14. M.S. Tite, I.C. Freestone, N. Wood, An investigation into the relationship between the raw materials used in the production of Chinese porcelain and stoneware bodies and the resulting microstructures, Archaeometry 54[1] (2012) 37-55.

15. Y.A. Qu, J. Xie, X.Q. Xi, C.J. Huang, J.L. Yang, Microstructure characteristics of blue-and-white porcelain from the folk kiln of Ming and Qing Dynasties, Ceramics Int. 40[6] (2014) 87838790.

16. H.S. Cheng, B. Zhang, D. Zhu, F.J. Yang, X.M. Sun, M.S. Guo, Some new results of PIXE study on Chinese ancient porcelain, Nucl. Instr. \& Meth. Phys. Res. Sect. B - Beam Inter. Mater. Atoms 240[1-2] (2005) 527-531.

17. F. Du, B.R. Su, Further study of sources of the imported cobalt-blue pigment used on Jingdezhen porcelain from late 13 to early 15 centuries, Sci. China Series E - Techn. Sci. 51[3] (2008) 249-259.

18. G. Simsek, Ph. Colomban, S. Wong, B. Zhao, A. Rougeulle, N.Q. Liem, Toward a fast nondestructive identification of pottery: The sourcing of 14th-16th century Vietnamese and Chinese ceramic shards, J. Cult. Her. 16[2] (2015) 159-172.

19. T.Q. Zhu, X. Ding, C.M. Kusimba, Z.Y. Feng, Using laser ablation inductively coupled plasma mass spectroscopy (LA-ICP-MS) to determine the provenance of the cobalt pigment of Qinghua porcelain from Jingdezhen in Yuan Dynasty of China (1271-1368AD), Ceramics Int. 41[8] (2015) 9878-9884.

20. Ph. Colomban, G. Sagon, X. Faurel, Differentiation of antique ceramics from the Raman spectra of their coloured glazes and paintings, J. Raman Spectrosc. 32[5] (2001) 351-360.

21. Ph. Colomban, V. Milande, L. Le Bihan, On-site Raman Analysis of Iznik pottery glazes and pigments, J. Raman Spectrosc. 35 (2004) 527-535.

22. B. Kirmizi, Ph. Colomban, B. Quette, On-site Analysis of Chinese Cloisonné enamels from $15^{\text {th }}$ to $19^{\text {th }}$ century, J. Raman Spectrosc. 41[7] (2010) 780-790.

23. Y. Su, L. Qu, H. Duan, N. Tarcea, A. Shen, J. Popp, J. Hu, Elemental analysis-aided Raman spectroscopic studies on Chinese cloisonné wares and Painted enamels from the Imperial Palace, Spectrochimica Acta Part A - Mol. Biomol. Spectrosc. 153 (2015) 165-170.

24. J. Henderson, M. Tregear, N. Wood, The technology of sixteenth- and seventeenth century Chinese cloisonné enamels, Archaeometry 31[2] (1989] 133-146.

25. N.Q. Liem, Ph. Colomban, G. Sagon, H.X. Tinh, T.B. Hoanh, Microstructure, Composition and Processing of the $15^{\text {th }}$ century Vietnamese Porcelains and Celadons, J. Cultural Heritage 4[3] (2003) 187-197. 
26. Ph. Colomban, G. Sagon, L.Q. Huy, N.Q. Liem, L. Mazerolles, Vietnamese ( $15^{\text {th }}$ century) blueand-white, tam thai and "luster" porcelains/stoneware: glaze composition and decoration techniques, Archaeometry 46[1] (2004) 125-136.

27. J.F. Cui, Y. Lei, Y., Z.B. Jin, B.L. Huang, X.H. Wu, Lead isotope analysis of Tang sancai pottery glazes from Gongiyi kiln, Henan province and Huangbao kiln, Shaanxi province, Archaeometry 52[4] (2010) 597-604.

28. W.D. Li, J.Z. Li, J. Wu, J.K. Guo, Study on the phase-separated opaque glaze in ancient China from Qionglai kiln, Ceramics Int. 29|8] (2003) 933-937.

29. W.D. Li, J. Wu, J.Z. Li, J.K. Guo, Study on the green glaze from Qionglai kiln site in Sichuan: One of the earliest phase-separated opaque glazes in China, Materials Issues in Art and Archaeology VI, Mater. Res. Soc. Symp. Proc. 712 (2002) 365-373.

30. C. Wang, Nomenclature for Painted Enamel on Porcelain in Qing Dynasty: A Scientific Viewpoint", The National Palace Museum Research Quarterly 29:3 (2012), 115-166.

31. J. Miao, B. Yang, D. Mu, Identification and differentiation of opaque Chinese overglaze yellow enamels by Raman spectroscopy and supporting techniques, Archaeometry 52[1] (2010) 146155.

32. H.A. Crosby Forbes, Yang-ts'ai: The Foreign Colors, China Trade Museum, Milton, 1982.

33. H. Garner, The origins of Famille Rose, Trans. Oriental Ceram. Soc. 37 (1969) 1-16.

34. G.C. Williamson, The book of Famille Rose, Kegan P., Trench, Trubner \& Co., London, 1937.

35. G. Loehr, Missionary-artist at the Manchu Court, Trans. Oriental Ceram. Soc. 34 (1962-1963) 51-67.

36. Père d'Entrecolle's letters from Ching-te-chen in 1712 and 1722, translated in R. Tichane, Ching-te-Chen, New York State Institute for Glaze Research, Painted Post, New York, 1983.

37. I. Landry-Deron, Les mathématiciens envoyés en Chine par Louis XIV en 1685, Arch. Hist. Exact. Sci. 55 (2001) 423-463.

38. C.F. Shih, Evidence of East-West Exchange in the Eighteenth Century: the Establishment of Painted Enamel Art at the Qing Court in the Reign of Emperor Kangxi, National Palace Museum Research Quarterly, 24[3], (2007) 45-94.

39. C.F. Shih, Riyue guanghua :Qinggong hua falang 日月光華 : 清宮畫珐瑯 (Radiant Luminance: The Painted Enamelware of the Qing Imperial Court). Taipei: The National Palace Museum of Taipei2012.

40. X.D. Xu, Europe-China-Europe: The Transmission of the Craft of Painted Enamel in the Seventeenth and Eighteenth Centuries, Goods from the East, 1600-1800 Trading Eurasia, Maxine Berg ed. , Houndmills, Basingstoke, Hampshire: Palgrave Macmillan, 2015, pp. $92-$ 106. 
41. G. Vogt, La porcelaine Chinoise, Bull. Soc. D'Encouragement pour l'Industrie Nationale, 99 (1900) 530-612.

42. Ph. Colomban, A. Tournié, L. Bellot-Gurlet, Raman Identification of glassy silicates used in ceramic, glass and jewellry: a tentative differentiation guide, J. Raman Spectrosc. 37 [8] (2006) 841-852.

43. Ph. Colomban, A. Tournié, M.-C. Caggiani, C. Paris Pigments and enamelling/gilding technology of Mamluk mosque lamps and bottle, J. Raman Spectrosc. 43[12] (2012) 19751984.

44. M.C. Caggiani, C. Valloteau, Ph. Colomban, Inside the glassmaker technology: Search of Raman criteria to discriminate between Emile Gallé and Philippe-Joseph Brocard Enamels and Pigment Signatures, J. Raman Spectrosc. 45[6] (2014) 456-464.

45. Ph. Colomban, I. Robert, C. Roche, G. Sagon, V. Milande, Identification des porcelaines "tendres" du $18^{\text {ème }}$ siècle par spectroscopie Raman: Saint-Cloud, Chantilly, Mennecy et Vincennes/Sèvres, Revue d'Archéométrie 28 (2004) 153-167.

46. D. Mancini, C. Dupont-Logié, Ph. Colomban, On-site identification of Sceaux porcelain and faience using a portable Raman instrument, Ceramics International 42[13] (2016) 1491814927.

47. Ph. Colomban, The on-site/remote Raman analysis with portable instruments - A review of drawbacks and success in Cultural Heritage studies and other associated fields, J. Raman Spectrosc. 43 (2012) 1529-1535.

48. L. Prinsloo, N. Wood, M. Loubser, S.M.C. Verryn, S. Tiley, Re-dating of Chinese celadon shards excavated on Mapungubwe Hill, a 13(th) century iron age site in South Africa, using Raman spectroscopy, XRF and XRD, J. Raman Spectrosc. 36[8] (2005) 806-816.

49. V. Notin, L'émail peint: de Limoges à Pékin, Bull. Soc. Archéolog. \& Histor. Limousin, CXL (2012) 85-107.

50. B. Zhao, G. Wang, I. Biron, Ph. Colomban, L. Hilaire-Pérez, La circulation des techniques de I'émail entre la France et la Chine du XVIIème au XIXème siècle, Le Cnrs en Chine Bulletin 21 (2016) 21-25. http://www.cnrs.fr/derci/IMG/pdf/cnrsenchine $21 \mathrm{fr}$ final pour le site cnrs.pdf

51. Ph. Colomban, F. Treppoz, Identification and Differentiation of Ancient and Modern European Porcelains by Raman Macro- and Microspectroscopy, J. Raman Spectr. 32 (2001) 93-102.

52. Ph. Colomban, O. Paulsen, Raman Determination of the Structure and Composition of Glazes, J. Amer. Ceram. Soc. 88[2] (2005) 390-395. 
53. P. Ricciardi, Ph. Colomban, Raman spectroscopy of ceramic and glass, In IR \& Raman spectroscopy in Forensic Sciences, J.M. Chalmers, H.G.M. Edwards, M. Hargreaves Eds, Wiley \& Sons Ltd, 2012, PP. 469-479,

54. Ph. Colomban, Non-destructive Raman analysis of ancient glasses and glazes, ch. 4.2, in Modern Methods for Analysing Archaeological and Historical Glass, First Edition, K. Janssens Ed, J. Wiley \& Sons Ltd 2012, pp. 275-300.

55. Ph. Colomban, Pottery, Glass and Enamelled Artefacts: How to Extract Information on their Manufacture Technology, Origin and Age? Ch. 8, In Analytical Archaeometry H. Howell \& P. Vandenabeele Eds, Royal Society of Chemistry, Cambridge, 2012, pp 245-267.

56. F. Froment, A. Tournié, Ph. Colomban, Raman identification of natural red to yellow pigments: ochre and iron-containing ores, J. Raman Spectrosc. 39[5] (2008) 560-568.

57. P. Ricciardi, Ph. Colomban, A. Tournié, V. Milande, Non-destructive on-site identification of ancient glasses: genuine artefacts, embellished pieces or forgeries?, J. Raman Spectrosc. 40 (2009) 604-617.

58. B. Kirmizi, H. Gokturk, Ph. Colomban, Colouring Agents in the Pottery Glazes of Western Anatolia: A New Evidence for the Use of Naples Yellow Pigment Variations during the Late Byzantine Period, Archaeometry 57 [3] (2015) 476-496.

59. M. Pereira, T. de Lacerda-Aroso, M.J.M. Gomes, A. Mata, L.C. Alves, Ph. Colomban, Ancient Portuguese Ceramic Wall Tiles (« Ajulejos »): Characterization of the Glaze and Ceramic Pigments, J. Nano Research 8 (2009) 79-88.

60. C. Sandalinas, S. Ruiz-Moreno, Lead-tin-antimony yellow. Historical manufacture molecular characterization and identification in seventeenth-century Italian paintings, Stud. Conserv. 40 (2004) 41-53.

61. C. Sandalinas, S. Ruiz-Moreno, A. Lopez-Gil, J. Miralles, Experimental confirmation by Raman spectroscopy of a $\mathrm{Pb}-\mathrm{Sn}$-Sb triple oxide yellow pigment in sixteenth-century Italian pottery, J. Raman Spectrosc. 37 (2006) 1146-1153.

62. F. Rosi, V. Manualli, C. Milliani, B.G. Brunetti, A. Sgamellotti, T. Grygar, D. Hradil, Raman scattering features of lead pyroantimonate compounds. Part I: XRD and Raman characterization of Pb2Sb2O7 doped with tin and zinc, J. Raman Spectrosc. 40 (2009) 107111.

63. C. Pelosi, G. Agresti, U. Santamaria, E. Mattei, Artifical yellow pigments: Production and characterization through spectroscopic methods of analysis, ePreservationScience 7 (2010) 108-115.

64. M.-C. Caggiani, Ph. Colomban, Raman identification of strongly absorbing phases: the ceramic black pigments, J. Raman Spectrosc. 42[4] (2011) 839-843. 
65. S. Karlin, Ph. Colomban, Raman Study of the Chemical and Thermal Degradation of AsReceived and Sol-Gel Embedded Nicalon and Hi-Nicalon SiC Fibres Used in Ceramic Matrix Composites, J. Raman Spectrosc. 28 (1997) 219-228.

66. Ph. Sciau, L. Noé, Ph. Colomban, Metal nanoparticles in contemporary potters' master pieces: Lustre and red "pigeon blood" pottery: Models to understand the ancient technology, Ceramics Int. 42[14] (2016) 15349-15357.

67. F. Koleini, L. C. Prinsloo, W. Biemond, Ph. Colomban, A.-T. Ngo, J.C.A. Boeyens, M.M. Van der Ryst, K. van Brakel, Unravelling the glass trade bead sequence from Magoro hill, South Africa: separating pre-seventeenth-century Asian imports from later European counterparts, Heritage Science 4 (2016) 43

68. T. Mouri, M. Enami, Raman spectroscopic study of olivine-group mineral, J. Mineralog. \& Petrolog. Sci., 103 (2008) 100-104.

69. E. Neri, C. Morvan, Ph. Colomban, M. P. Guerra, V. Prigent, Late Roman and Byzantine Mosaic opaque "Glass-ceramics" Tesserae ( $5^{\text {th }}-9^{\text {th }}$ century), Ceramics Int. 42[16] (2016) 1885918869.

70. Ph. Colomban, C. Truong, A Non-destructive Raman Study of the Glazing Technique in Lustre Potteries and Faiences $\left(9^{\text {th }}-14^{\text {th }}\right.$ centuries): Silver ions, Nanoclusters, Microstructure and Processing, J. Raman Spectrosc. 35[3] (2004) 195-207.

71. L.F. Vieira Ferreira, I.F. Ferreira Machado, A.M. Ferraria, T.M. Casimiro, P. Portuguese tinglazed earthenware from the 16th century: A spectroscopic characterization of pigments, glazes and pastes, Appl. Surf. Sci. B 285 (2013) 144-152.

72. M. Tite, O. Watson, T. Pradell, M. Matin, G. Molina, K. Domoney, A. Bouquillon, Revisiting the beginnings of tin-opacified Islamic glazes, J. Archaeolog. Sci. 57 (2015) 80-91.

73. A. Silvestri, F. Nestola, L. Peruzzo, Multi-methodological characterisation of calcium phosphate in late-antique glass mosaic tesserae, Microchemical J. 124 (2016) 811-818.

74. Ph. Colomban, V. Milande, H. Lucas, On-site Raman Analysis of Medici Porcelain, J. Raman Spectrosc. 35[1] (2004) 68-72.

75. Ph. Colomban, Recent Case studies in the Raman Analysis of Ancient Ceramics: Glaze Opacification in Abbasid Pottery, Medici and $18^{\text {th }}$ century French Porcelains, Iznik and Kütahya Ottoman Fritwares and Unexpected Lapis Lazuli Pigment in Lajvardina Wares, Mater. Res. Soc. Proc. Symposium OO, vol 852, P. Vandiver, J. Mass \& A. Murray Eds, pp. 153-160.

76. B. Kirmizi, Ph. Colomban, M. Blanc, On-site Analysis of Limoges enamels from $16^{\text {th }}$ to $19^{\text {th }}$ century, J. Raman Spectrosc. 41[10] (2010) 1240-1247. 
77. J. Van Pevenage, D. Lauwers, D. Herremans, E. Verhaeven,B. Vekemans, W. De Clercq, L. Vincze, L. Moens, P. Vandenabeele, A Combined Spectroscopic Study on Chinese Porcelain Containing Ruan-Cai Colours, Anal. Methods 6 (2014) 387-394.

78. R. Giannini, I.C. Freestone, A.J. Shortland, European cobalt sources identification in the production of Chinese famille rose porcelain, J. Archaeolog. Sci. 80 (2016) 27-36.

79. B. Manoun, M. Azdouz, M. Azrour, R. Essehli, S. Benmokhtar, L. El Ammari, A. Ezzahi, A.Ider, P. Lazor, Synthesis, Rietveld Refinements and Raman Spectroscopic Studies of Tricationic Lacunar Apatites $\mathrm{Na}_{1-\mathrm{x}} \mathrm{K}_{\mathrm{x}} \mathrm{Pb}_{4}\left(\mathrm{AsO}_{4}\right)_{3}(0<\mathrm{x}<1)$, J. Mol. Struct. 986 (2011) 1-9.

80. H.G.M. Edwards, Ph. Colomban, B. Bowden, Raman spectroscopic analysis of an English softpaste porcelain plaque-mounted table, J. Raman Spectrosc. 35 (2004) 656-661.

81. P. Ricciardi, Ph. Colomban, V. Milande, Non-destructive raman characterization of Capo di Monte and Buen Retiro porcelain, J. Raman Spectrosc. 39 (2008) 1113-1119.

82. Ph. Colomban, L. Arberet, B. Kirmizi, On-site Raman analysis of 17 th and 18 th century Limoges enamels: Implications on the European cobalt sources and the technological relationship between Limoges and Chinese enamels, Ceramics Int. http://dx.doi.org/10.1016/i.ceramint.2017.05.040

83. R.G.V. Hancock, J. McKechnie, S. Aufreiter, K. Karklins, M. Kapches, M. Sempowski, J.F. Moreau, I. Kenyon, Non-destructive analysis of European cobalt blue glass trade beads, J. Radioanal. \& Nucl. Chem. 244[3] (2000) 567-573.

84. F. Koleini F. Koleini, L. C. Prinsloo, W. Biemond, Ph. Colomban, A.-T. ngo, J.C.A. Boeyens, M.M. Van der Ryst, K. van Brakel, Unravelling the glass trade bead sequence from Magoro hill, South Africa: separating pre-seventeenth-century Asian imports from later European counterparts, Heritage Science 4 (2016) 43 http://dx.doi.org/10.1186/s40494-016-0113-2

85. R.G.V. Hancock, J. McKechnie, S. Aufreiter, K. Karklins, M. Kapches, M. Sempowski, J.F. Moreau, I. Kenyon, Non-destructive analysis of European cobalt blue glass trade beads, J. Radioanal. \& Nucl. Chem. 244[3] (2000) 567-573.

86. Ph. Colomban, Rocks as blue (green and black) pigments/dyes of glazed pottery and enamelled glass artefacts - The potential of Raman microscopy, European Mineralogy Journal 25[5] (2013) 863-879.

87. M.O. Figueiredo, T.P. Silva, J.P. Veiga, A XANES study of cabalt speciation state in blue-andwhite glazes from $16^{\text {th }}$ to $17^{\text {th }}$ century Chinese porcelains, J. Electr. Spectrosc. \& Rel. Phenom. 185 (2012) 97-102. 
88. M.I. Dias, M.I. Prudêncio, M.A. Pinto de Matos, A.L. Rodrigues, Tracing the origin of blue and white Chinese Porcelain ordered for the Portugese market during the Ming dynasty using INAA, J. Arcaeolog. Sci; 40 (2013) 3046-3057.

89. C. Fischer, E. Hsieh, Export Chinese Blue-and-white porcelain: compositional analysis and sourcing using non-invasive portable XRF and reflectance spectroscopy, J. Archaeolog. Sci. 80 (2016) 14-26.

90. B. Gratuze, I. Soulier, M. Blet, L. Vallauri, De l'origine du cobalt: du verre a`la céramique“, Revue d'archéométrie 20 (1996) 77-104.

91. L.F. Vieira Ferreira, A. Gonzalez, M.F.C. Pereira, L.F. Santos, T.M. Casimiro, D.P. Ferreira, D.S. Conceicao, I.F. Machado, Spectroscopy of 16th century Portuguese tin-glazed earthenware produced in the region of Lisbon, Ceramics Int. 41 (2015) 13433-13446.

92. G. Simsek, Ph. Colomban, F. Casadio,' L. Bellot-Gurlet, K. Faber, G. Zelleke, V. Milande, L. Tilliard, On-site identification of early Böttger red stonewares using portable XRF/Raman instruments: 2, glaze and gilding analysis, J. Am. Ceramic Society 98[10] (2015) 3006-3013.

93. P. Sciau Reverse engineering the ancient ceramic technology based on X-ray fluorescence spectromicroscopy, J. Anal. At. Spectrom. 26 (2011) 969-979. doi:10.1039/C0JA00212G. 
Table 1: Studied artefacts

\begin{tabular}{|c|c|c|c|c|}
\hline $\begin{array}{l}\text { MNAAG } \\
\text { inventory } \\
\text { number }\end{array}$ & Type & Date (expected) & Production & Marks \\
\hline G 1351 & $\begin{array}{l}\text { doucai } \\
\text { bowl }\end{array}$ & $\begin{array}{l}\text { Wanli reign (1572- } \\
\text { 1620) } \\
\text { Ming Dynasty }\end{array}$ & $\begin{array}{l}\text { Imperial manufacture of } \\
\text { Jingdezhen }\end{array}$ & “Da Ming Wanli nian zhi” mark \\
\hline G 5250 & $\begin{array}{l}\text { huafalang } \\
\text { bowl }\end{array}$ & $\begin{array}{l}\text { Final period of the } \\
\text { Kangxi reign (c. } \\
1715-1722)\end{array}$ & $\begin{array}{l}\text { Painted enamels made in } \\
\text { the Palace workshop (The } \\
\text { Palace Board of Works) }\end{array}$ & “Kangxi yu zhi” mark \\
\hline G 4806 & $\begin{array}{l}\text { huafalang/yangcai } \\
\text { bowl }\end{array}$ & $\begin{array}{l}\text { Yongzheng reign } \\
(1723-1735)\end{array}$ & $\begin{array}{l}\text { Painted enamels made in } \\
\text { the Imperial manufacture } \\
\text { of Jingdezhen }\end{array}$ & $\begin{array}{l}\text { "Yongzheng } \\
\text { yu zhi" mark }\end{array}$ \\
\hline G 913 & $\begin{array}{l}\text { huafalang/yangcai } \\
\text { bowl }\end{array}$ & $\begin{array}{l}\text { Yongzheng reign } \\
(1723-1735)\end{array}$ & $\begin{array}{l}\text { Painted enamels made in } \\
\text { the Imperial manufacture } \\
\text { of Jingdezhen }\end{array}$ & "Yongzheng yu zhi" mark \\
\hline G 822 & $\begin{array}{l}\text { Famille verte } \\
\text { dish }\end{array}$ & c. 1721 & $\begin{array}{l}\text { Imperial manufacture of } \\
\text { Jingdezhen }\end{array}$ & $\begin{array}{l}\text { "Da Qing Kangxi nian zhi" mark on the } \\
\text { base/"wanshou wujiang" inscriptions in reserve } \\
\text { on the inter rim (made in c. } 1713 \text { for the 60th } \\
\text { birthday of the emperor) }\end{array}$ \\
\hline G 5615 & $\begin{array}{l}\text { Famille verte } \\
\text { bowl }\end{array}$ & $19^{\text {th }} \mathrm{c}$. & Private kiln (Jingdezhen) & \\
\hline G 3361 & $\begin{array}{l}\text { Famille rose } \\
\text { Water dropper }\end{array}$ & early $18^{\text {th }} \mathrm{c}$. & $\begin{array}{l}\text { Imperial manufacture of } \\
\text { Jingdezhen }\end{array}$ & “Da Qing Kangxi nian zhi” mark \\
\hline G 4551 & $\begin{array}{l}\text { Famille verte } \\
\text { cup }\end{array}$ & $1^{\text {st }}$ half $18^{\text {th }} \mathrm{c}$. & Private kiln (Jingdezhen) & “JL" mark = J. Landin (1627-1695) mark \\
\hline MG 7368 & $\begin{array}{l}\text { doucai } \\
\text { bowl }\end{array}$ & $18^{\text {th }} \mathrm{c}$. & Private kiln (Jingdezhen) & “Da Qing Yongzheng nian zhi” mark \\
\hline G 4611 & $\begin{array}{l}\text { doucai } \\
\text { cup }\end{array}$ & $18^{\text {th }} \mathrm{c}$. & $\begin{array}{l}\text { Imperial manufacture of } \\
\text { Jingdezhen /Private kiln } \\
\text { (Jingdezhen) }\end{array}$ & $\begin{array}{l}\text { "Da Ming Chenghua (1464-1487) nian zhi” } \\
\text { apocryphal mark }\end{array}$ \\
\hline G 5068 & $\begin{array}{l}\text { doucai } \\
\text { pot }\end{array}$ & $18^{\text {th }} \mathrm{c}$. & $\begin{array}{l}\text { Imperial manufacture of } \\
\text { Jingdezhen /Private kiln } \\
\text { (Jingdezhen) }\end{array}$ & “Da Ming Chenghua nian zhi” apocryphal mark \\
\hline G 5696 & $\begin{array}{l}\text { doucai } \\
\text { bowl }\end{array}$ & $\begin{array}{l}2^{\text {nd }} \text { half } 17^{\text {th }}-\text { early } \\
18^{\text {th }} \mathrm{c} .\end{array}$ & $\begin{array}{l}\text { Imperial manufacture of } \\
\text { Jingdezhen }\end{array}$ & “Da Qing Kangxi nian zhi” mark \\
\hline G 5609 & $\begin{array}{l}\text { Famille verte } \\
\text { seal }\end{array}$ & $17^{\text {th }} ? 19^{\text {th }} ?$ & $\begin{array}{l}\text { Imperial manufacture of } \\
\text { Jingdezhen ? Private kiln } \\
\text { (Jingdezhen)? }\end{array}$ & “Kangxi yulan zhi bao" inscriptions \\
\hline G 4374 & $\begin{array}{l}\text { wucai } \\
\text { vase }\end{array}$ & $\begin{array}{l}\text { end } 16^{\text {th }}-\text { mid. } \\
17^{\text {th }} c .\end{array}$ & Private kiln (Jingdezhen) & \\
\hline MG 5806 & $\begin{array}{l}\text { wucai } \\
\text { vase }\end{array}$ & $\begin{array}{l}\text { mid-later half } 17^{\text {th }} \\
\text { c. }\end{array}$ & Private kiln (Jingdezhen) & \\
\hline G 5687 & $\begin{array}{l}\text { wucai } \\
\text { vase }\end{array}$ & mid $17^{\text {th }} \mathrm{c}$ & Private kiln (Jingdezhen) & \\
\hline G 1710 & $\begin{array}{l}\text { Famille } \\
\text { noire/Famille verte } \\
\text { Vase }\end{array}$ & $\begin{array}{l}\text { Later half } 17^{\text {th }}- \\
\text { early } 18^{\text {th }} c .\end{array}$ & Private kiln (Jingdezhen) & “Biyu tang zhi”mark \\
\hline G 421 & $\begin{array}{l}\text { Famille verte } \\
\text { Vase }\end{array}$ & $\begin{array}{l}\text { end } 17^{\text {th }}-\text { early } \\
18^{\text {th }} \mathrm{c} \text {. }\end{array}$ & Private kiln (Jingdezhen) & \\
\hline MG 3668 & teapot & $2^{\text {nd }}$ half $18^{\text {th }} \mathrm{c}$ & Private kiln (Yixing) & \\
\hline MG 9604 & teapot & $2^{\text {nd }}$ half $18^{\text {th }} c$. & Private kiln (Yixing) & \\
\hline MG 8062 & bowl & $19^{\text {th }} \mathrm{c}$. & Private kiln (Yixing) & \\
\hline
\end{tabular}




\section{FIGURE CAPTIONS}
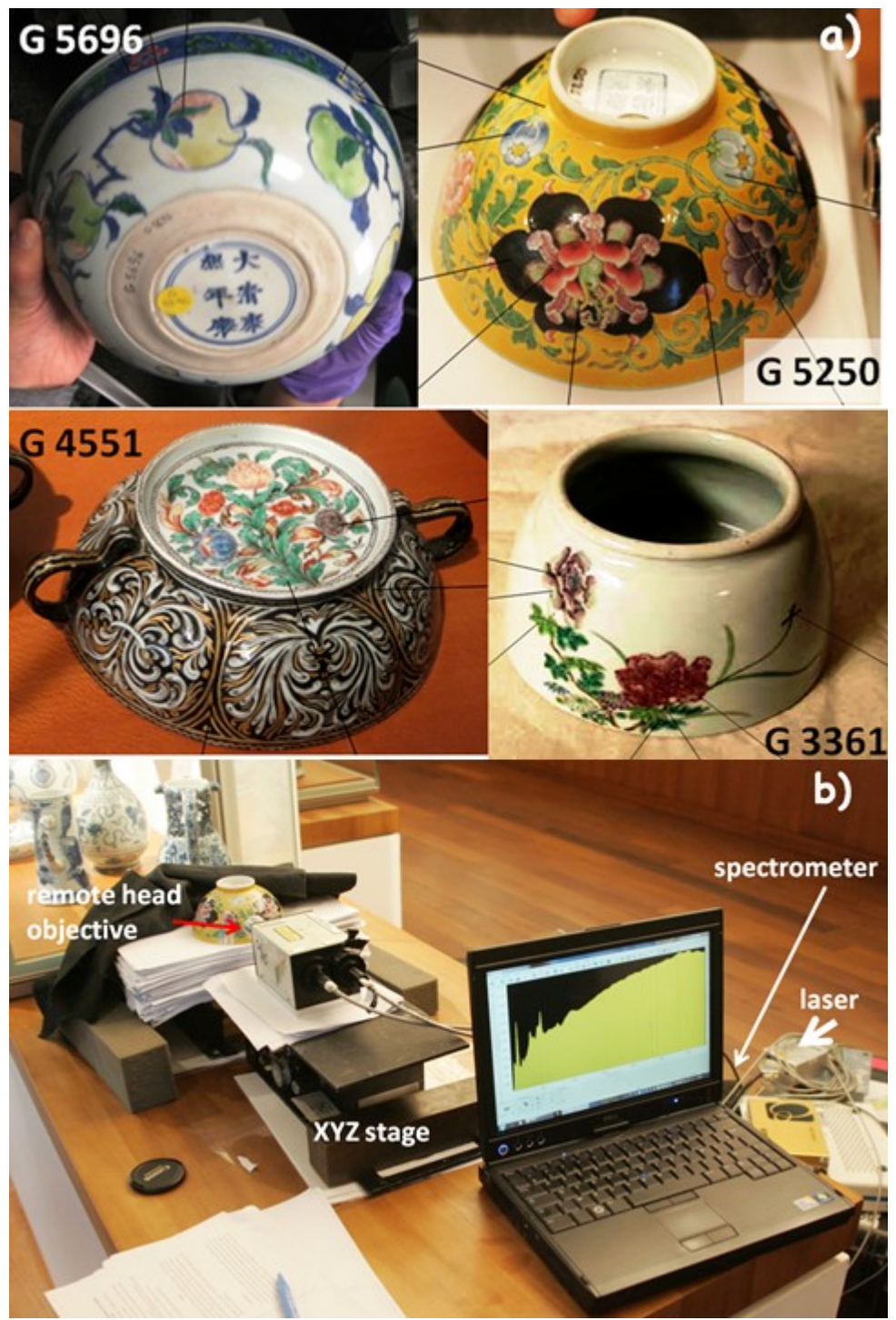

Fig. 1: a) Representative Qing Dynasty porcelains made respectively with 'Couleurs transparentes' (G 5696) and opaque/huafalang (G 5250, G 4551 and G 3361) enamels.(see Table 1 and Supplementary Materials for details; b) mobile Raman set-up. 

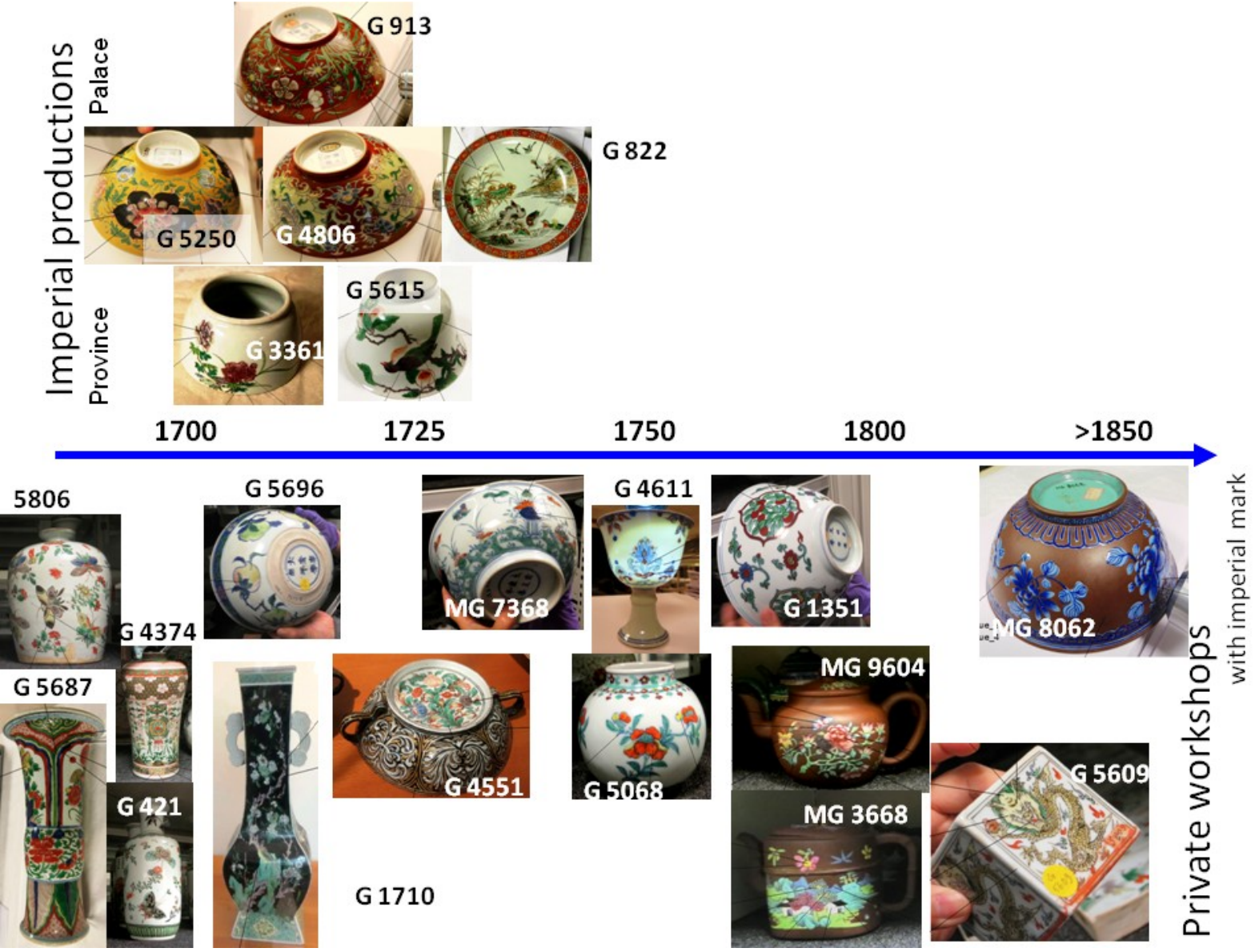

Fig. 2: Studied corpus (see Table 1). 


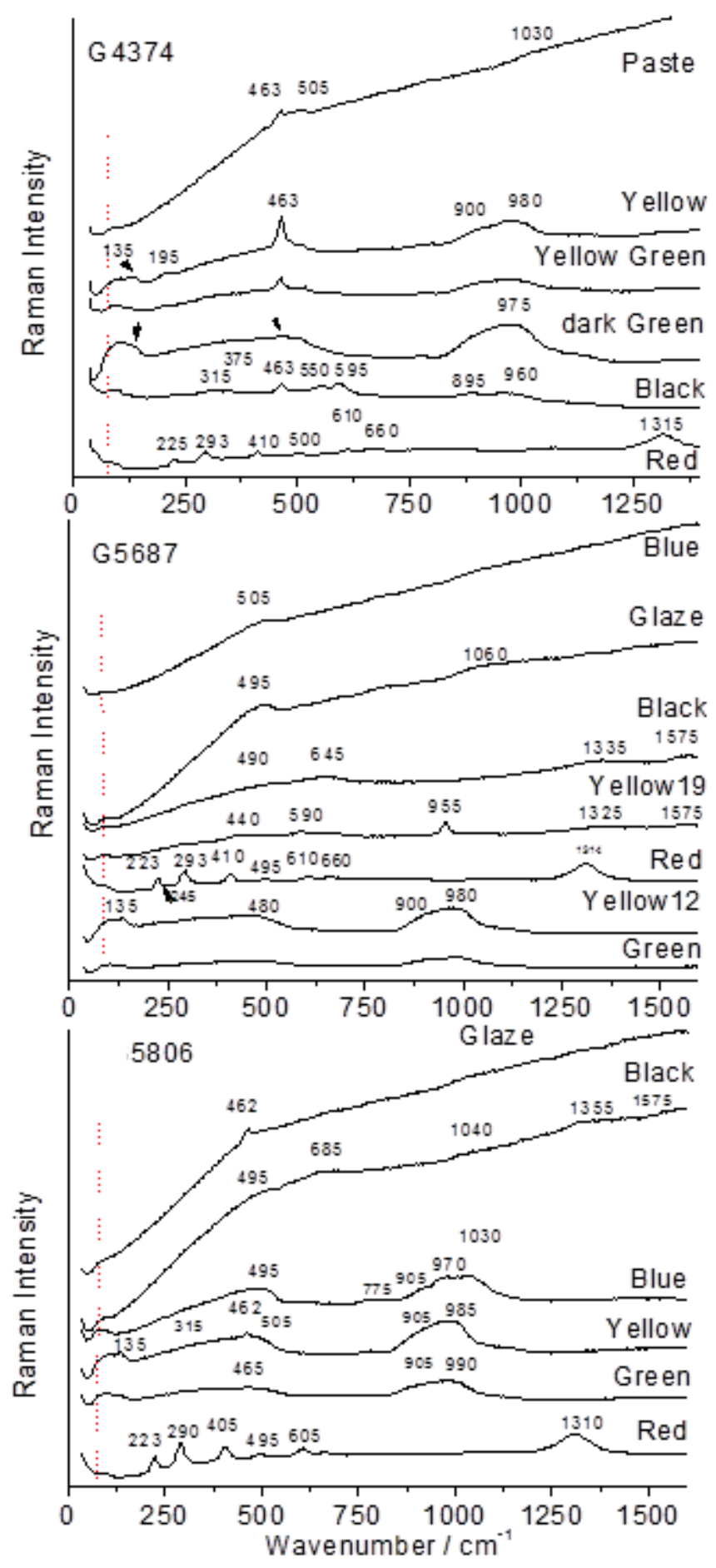

Fig. 3: Representative Raman spectra recorded on $17^{\text {th }}$ (or earlier) century artefacts (see Table 1 for details). 


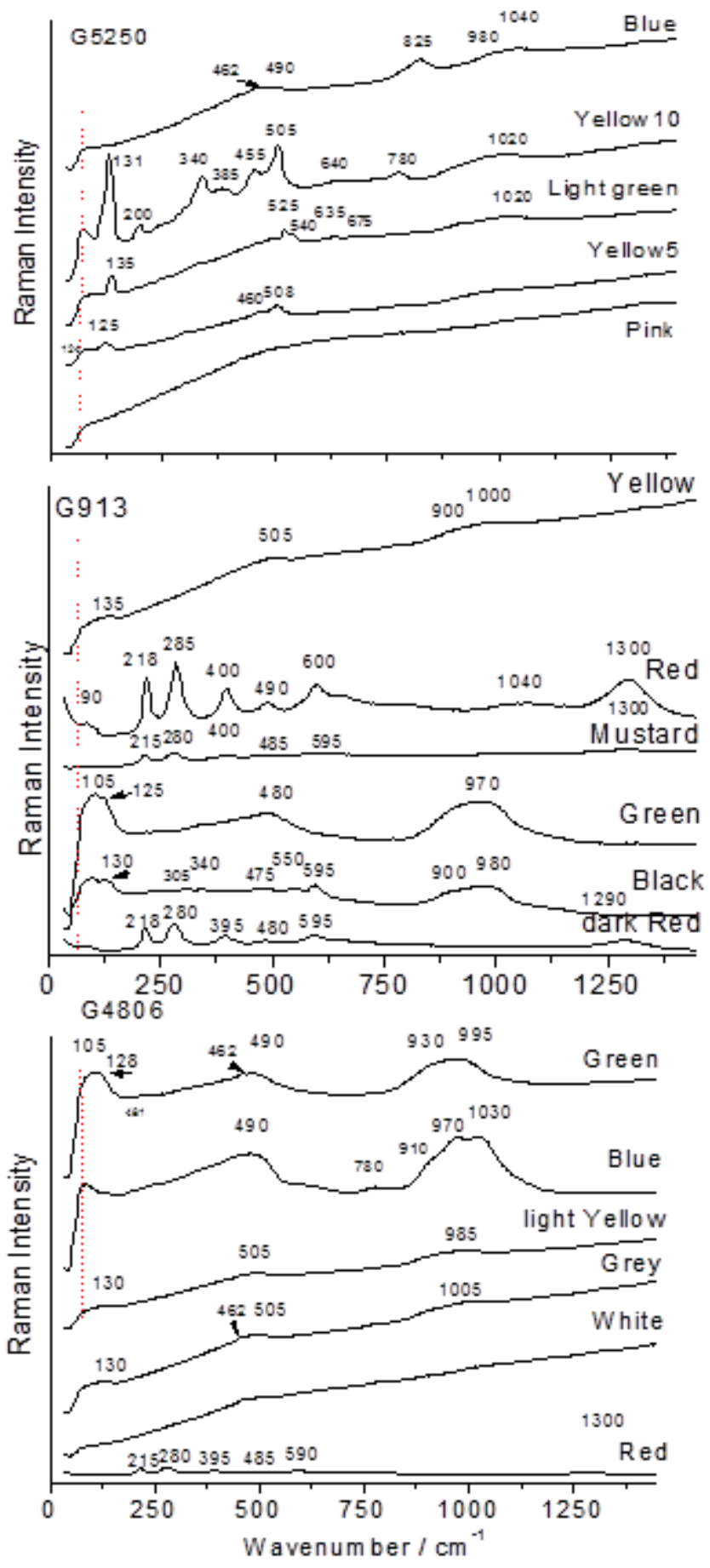

Fig. 4: Representative Raman spectra recorded on huafalang porcelains (imperial productions, before 1736, see Table 1). 

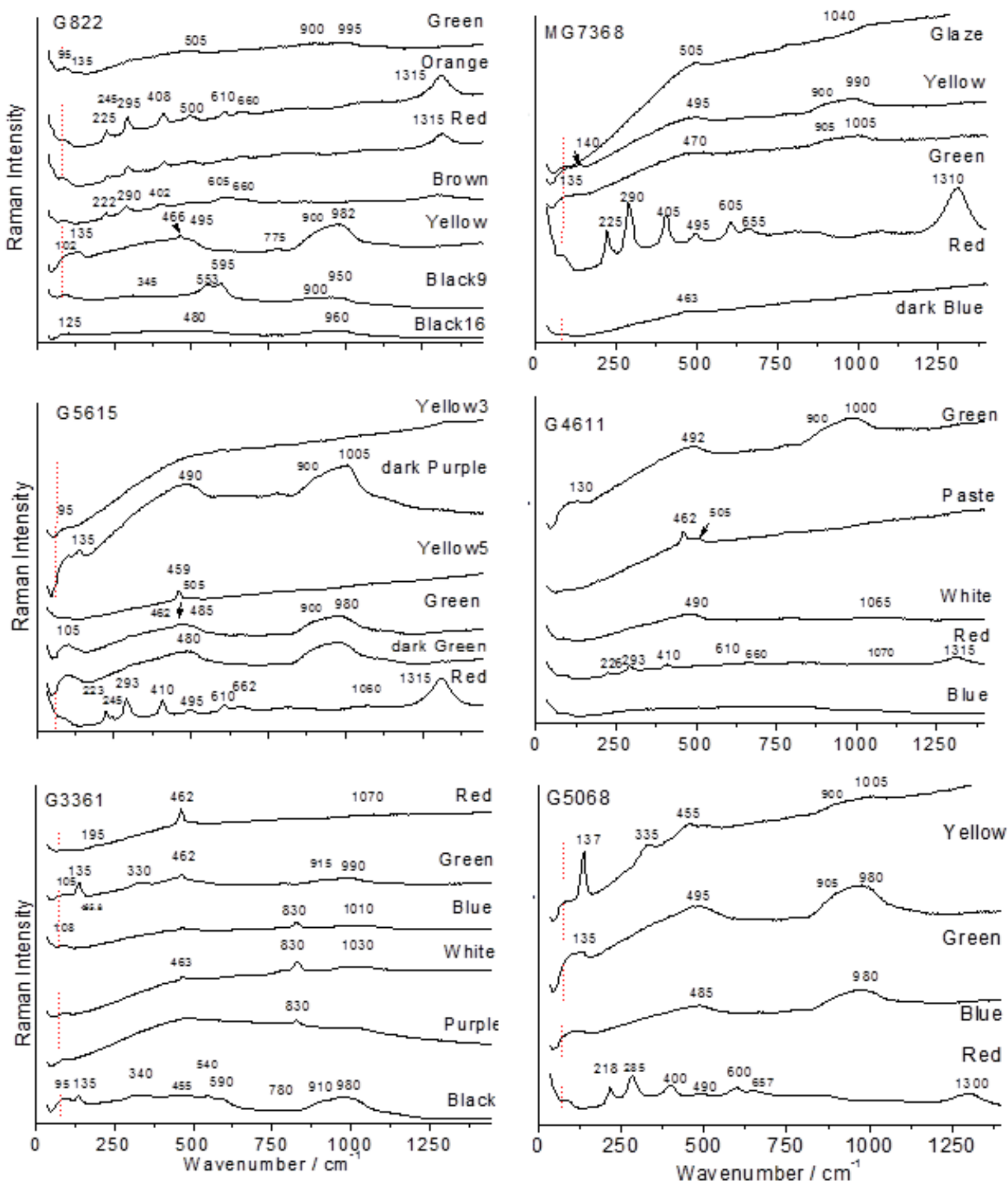

Fig. 5: Representative Raman spectra recorded on $18^{\text {th }}$ century imperial productions (left column) or with imperial mark (right column). 

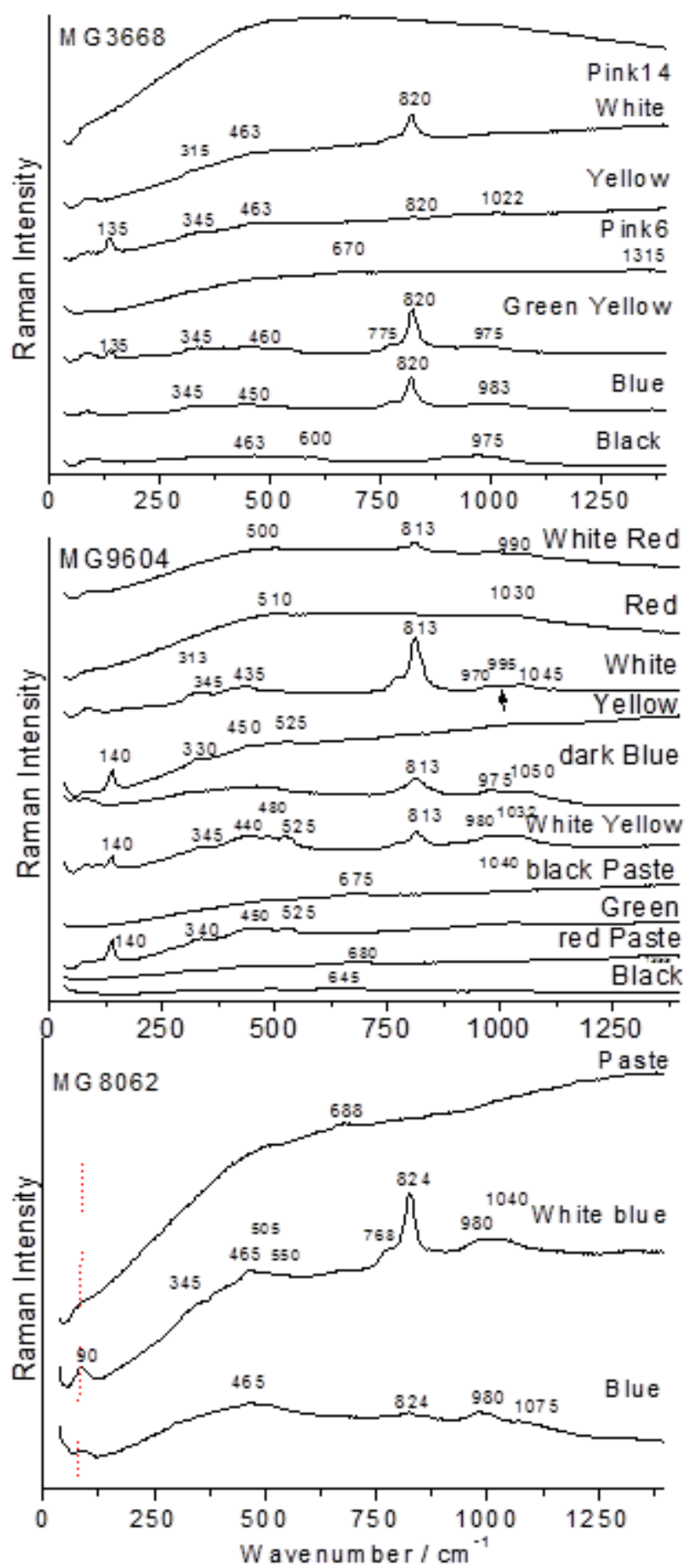

Fig. 6: Representative Raman spectra recorded on $2^{\text {nd }}$ half $18^{\text {th }}$ (MG 3668 \& MG 9604) and $19^{\text {th }}$ centuries painted Yixing stonewares. 
Supplementary Materials

Non-invasive Raman analyses of falangcai and related porcelain wares. Searching for evidence for innovative pigment technologies

$$
\text { Philippe Colomban, }{ }^{1 *} \text { Yizheng Zhang, }{ }^{1} \text { Bing Zhao, }{ }^{2}
$$

${ }^{1}$ Sorbonne Universités, UPMC Univ. Paris 06, MONARIS UMR8233, 4 Place Jussieu, 75005 Paris, France

${ }^{2}$ CNRS, Collège de France, CRCAO UMR8155, 52 rue Cardinal-Lemoine, 75005, Paris, France

*Corresponding author

Philippe.colomban@upmc.fr

All photos

Ph. Colomban - MNAAG Droits réservés 

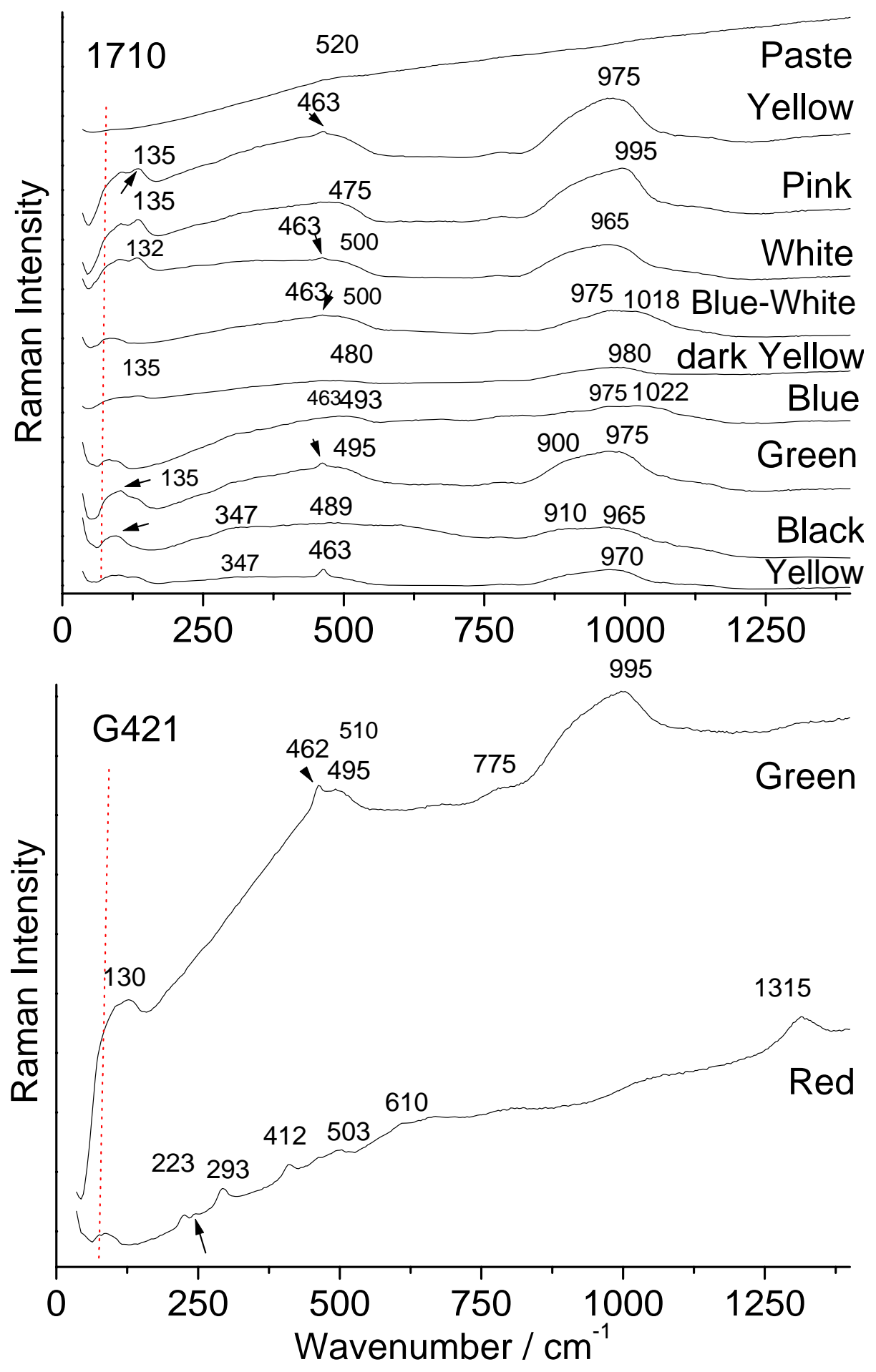

Fig. S1: Representative Raman spectra recorded in different coloured area of the 1710 and G421 artefacts, see Table 1. 

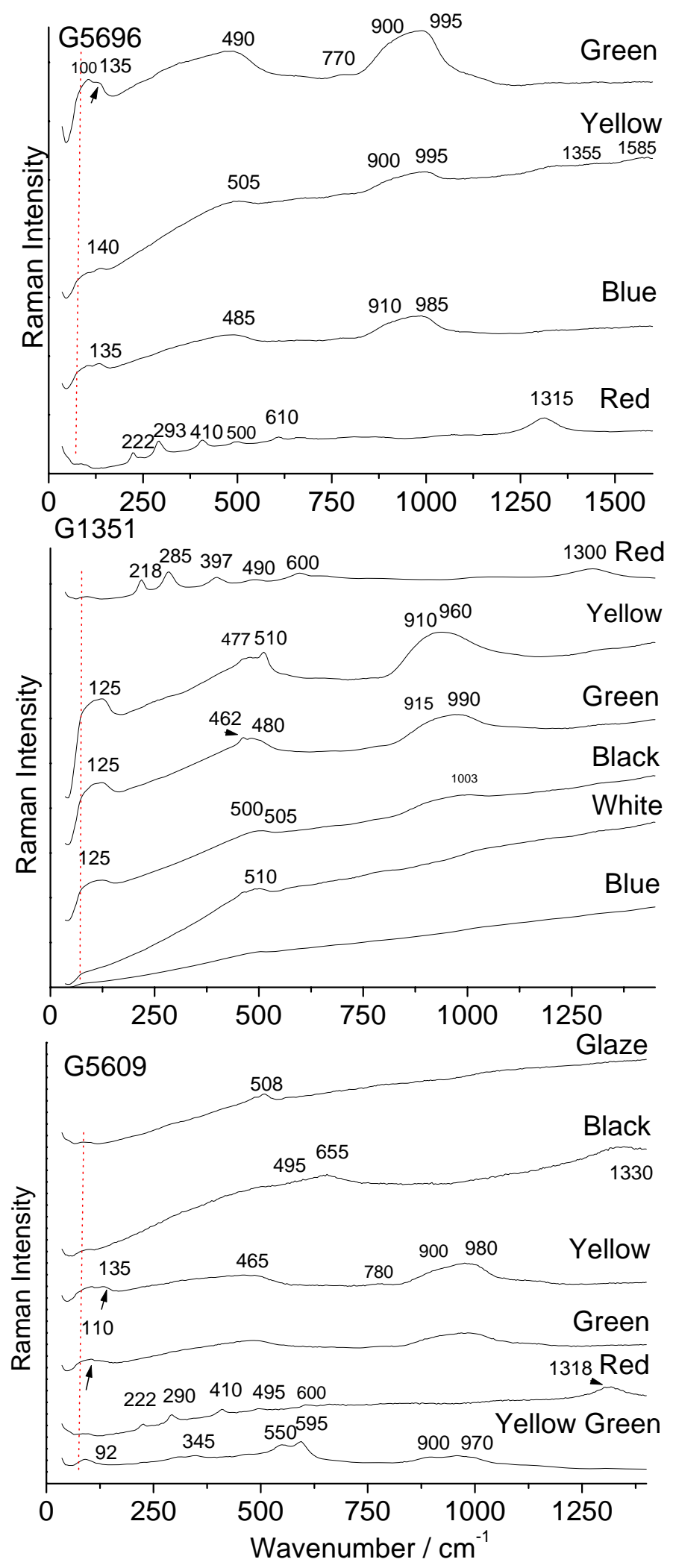

Fig. S2 : Representative Raman spectra recorded in different coloured area of the G5696, G1351 and G5609 artefacts, see Table 1. 
Table S1: Main Raman peak wavenumber and assignments

\begin{tabular}{|c|c|c|c|c|c|}
\hline \multirow[b]{2}{*}{$\begin{array}{l}\text { Reference } \\
\text { Number }\end{array}$} & \multicolumn{3}{|c|}{ Chromophore } & \multicolumn{2}{|c|}{ Matrix } \\
\hline & Color & Composition & $\begin{array}{l}\text { Characteristic } \\
\text { Peak } \\
\text { Wavenumber } \\
\left(\mathrm{cm}^{-1}\right)\end{array}$ & $\delta\left(\mathrm{cm}^{-1}\right)$ & $V\left(\mathrm{~cm}^{-1}\right)$ \\
\hline \multirow[t]{6}{*}{ G1351 } & Yellow & Naples Yellow & 511 & 477 & 939 \\
\hline & Red & Hematite & 218/285/1300 & - & - \\
\hline & Green & - & - & 462 & 481 \\
\hline & Black & - & - & 504 & 1003 \\
\hline & White & - & - & 500 & - \\
\hline & Blue & Naples Yellow & 511 & - & - \\
\hline \multirow[t]{6}{*}{ G822 } & Black & - & - & $553 / 594$ & $900 / 950$ \\
\hline & Yellow & Naples Yellow & 131 & 466 & 982 \\
\hline & Brown & $\begin{array}{l}\text { Hematite } \\
\text { Carbon }\end{array}$ & $\begin{array}{c}222 / 289 / 1303 \\
1582\end{array}$ & - & - \\
\hline & Red & Hematite & $226 / 293 / 1314$ & - & - \\
\hline & Orange & Hematite & $226 / 293 / 1314$ & - & - \\
\hline & Green & Naples Yellow & 135 & 504 & $896 / 996$ \\
\hline \multirow[t]{6}{*}{ G4551 } & Green & - & - & 492 & 960 \\
\hline & Yellow & - & - & $485 / 504$ & 1018 \\
\hline & Black & - & - & 473 & $971 / 1021$ \\
\hline & Yellow Black & Carbon & 1562 & $549 / 583$ & 953 \\
\hline & Purple & - & - & 504 & 993 \\
\hline & Red & Hematite & $222 / 293 / 1314$ & - & - \\
\hline \multirow[t]{6}{*}{ G4806 } & Green & - & - & $462 / 489$ & 979 \\
\hline & Blue & - & - & 481 & $971 / 1028$ \\
\hline & Yellow & Naples Yellow & 131 & 504 & 989 \\
\hline & Grey & Naples Yellow & 131 & 504 & 1003 \\
\hline & White & - & - & 504 & - \\
\hline & Red & Hematite & $214 / 281 / 1286$ & - & - \\
\hline \multirow[t]{5}{*}{ G5696 } & Green & Naples Yellow & 131 & 489 & 989 \\
\hline & Yellow & Naples Yellow & 139 & 504 & 996 \\
\hline & & Carbon & 1585 & & \\
\hline & Blue & - & - & 485 & 989 \\
\hline & Red & Hematite & $222 / 293 / 1314$ & - & - \\
\hline \multirow[t]{8}{*}{1710} & Pink & Naples Yellow & 136 & 474 & 993 \\
\hline & Yellow & Naples Yellow & 136 & 463 & 968 \\
\hline & White & - & - & 463 & 965 \\
\hline & Blue White & - & - & 463 & $975 / 1018$ \\
\hline & Black Yellow & Naples Yellow & 136 & 482 & 975 \\
\hline & Blue & - & - & 493 & $975 / 1022$ \\
\hline & Green & - & - & 463 & 965 \\
\hline & Black & - & - & 489 & $911 / 961$ \\
\hline \multirow[t]{4}{*}{ MG9604 } & Yellow & Naples Yellow & $140 / 347 / 523$ & 459 & 1039 \\
\hline & White Red & Arsenate & 813 & 501 & 990 \\
\hline & Red & - & - & 508 & 1029 \\
\hline & White & Arsenate & 813 & 436 & $997 / 1047$ \\
\hline
\end{tabular}




\begin{tabular}{|c|c|c|c|c|c|}
\hline & White Yellow & $\begin{array}{c}\text { Naples Yellow } \\
\text { Arsenate }\end{array}$ & $\begin{array}{c}140 / 341 / 523 \\
817\end{array}$ & $440 / 481$ & $979 / 1032$ \\
\hline & Green & Naples Yellow & $140 / 340 / 523$ & 451 & 1039 \\
\hline & Black & $\mathrm{MnO}_{2}$ & 647 & 482 & 975 \\
\hline & Blue & Arsenate & 813 & 459 & $975 / 1050$ \\
\hline \multirow[t]{4}{*}{ G4611 } & Green & Naples Yellow & 131 & 492 & 1003 \\
\hline & White & Arsenate & 805 & 489 & 1067 \\
\hline & Red & Hematite & $226 / 293 / 1314$ & - & - \\
\hline & Blue & - & - & 508 & 1071 \\
\hline \multirow[t]{9}{*}{ G5687 } & Blue & - & - & 504 & - \\
\hline & Black & Carbon & $1334 / 1576$ & - & - \\
\hline & & $\mathrm{MnO}_{2}$ & 647 & & \\
\hline & Yellow 19 & Naples Yellow & 140 & - & - \\
\hline & & Carbon & $1324 / 1576$ & & \\
\hline & & $\mathrm{MnO}_{2}$ & 587 & & \\
\hline & Yellow 12 & Naples Yellow & 140 & 478 & 972 \\
\hline & Red & Hematite & $223 / 293 / 1314$ & - & - \\
\hline & Green & - & - & 482 & 972 \\
\hline \multirow[t]{6}{*}{ MG5806 } & Black & Carbon & $1355 / 1576$ & - & - \\
\hline & & $\mathrm{MnO}_{2}$ & 655 & & \\
\hline & Blue & - & - & 493 & $979 / 1029$ \\
\hline & Yellow & Naples Yellow & 136 & 463 & 979 \\
\hline & Green & - & - & 466 & 990 \\
\hline & Red & Hematite & $223 / 289 / 1304$ & - & - \\
\hline \multirow[t]{6}{*}{ G5615 } & Yellow & Carbon & 1586 & - & - \\
\hline & & $\mathrm{MnO}_{2}$ & 595 & & \\
\hline & Purple Black & Naples Yellow & 136 & 489 & 1004 \\
\hline & Green & - & - & 463 & 972 \\
\hline & Black Green & - & - & 482 & 972 \\
\hline & Red & Hematite & $223 / 293 / 1314$ & - & - \\
\hline \multirow[t]{7}{*}{ G4374 } & Yellow & Naples Yellow & 132 & 463 & 972 \\
\hline & Yellow Green & Naples Yellow & $355 / 520$ & 463 & 965 \\
\hline & Black & $\mathrm{MnO}_{2}$ & 595 & 463 & $893 / 958$ \\
\hline & & Fe3O4- & 550 & & \\
\hline & & $\mathrm{Cr}_{2} \mathrm{MnO}_{4}$ & & & \\
\hline & Dark Green & - & - & 463 & 975 \\
\hline & Red & Hematite & $227 / 293 / 1314$ & - & - \\
\hline \multirow[t]{4}{*}{ MG7368 } & Yellow & Naples Yellow & 140 & 497 & 990 \\
\hline & Green & Naples Yellow & 140 & 470 & 1004 \\
\hline & Red & Hematite & $228 / 289 / 1307$ & - & - \\
\hline & Dark Blue & - & - & 463 & - \\
\hline \multirow[t]{2}{*}{ MG8062 } & White Blue & Arsenate & 824 & 466 & $990 / 1022$ \\
\hline & Blue & Arsenate & 824 & 465 & $979 / 1071$ \\
\hline \multirow[t]{4}{*}{ G820 } & Green & - & - & 462 & 971 \\
\hline & Red & Hematite & $226 / 296 / 1314$ & - & - \\
\hline & Yellow & Naples Yellow & 135 & 462 & 971 \\
\hline & Purple & Naples Yellow & 135 & 481 & 989 \\
\hline \multirow[t]{5}{*}{ MG3668 } & White & Arsenate & 820 & 466 & - \\
\hline & Yellow & Naples Yellow & 136 & 463 & 1022 \\
\hline & Pink & Hematite & 1314 & - & - \\
\hline & Green Yellow & Naples Yellow & 136 & 459 & 975 \\
\hline & & $\mathrm{Co}_{2} \mathrm{SiO}_{4}$ & 824 & & \\
\hline
\end{tabular}




\begin{tabular}{|c|c|c|c|c|c|}
\hline & Blue & $\mathrm{Co}_{2} \mathrm{SiO}_{4}$ & 820 & 447 & 983 \\
\hline & Black & - & - & 463 & 972 \\
\hline \multirow[t]{7}{*}{ G5609 } & Black & Carbon & $1331 / 1563$ & - & - \\
\hline & & $\mathrm{MnO}_{2}$ & 655 & & \\
\hline & Yellow & Naples Yellow & 136 & 466 & 975 \\
\hline & Green & - & - & 478 & 986 \\
\hline & Red & Hematite & $227 / 293 / 1318$ & - & - \\
\hline & Yellow Green & Chromate & 344 & - & $900 / 958$ \\
\hline & & $\mathrm{Cr}_{2} \mathrm{O}_{3}$ & 550 & & \\
\hline \multirow[t]{5}{*}{ G5250 } & Blue & $\mathrm{CO}_{2} \mathrm{SiO}_{4}$ & 823 & $462 / 489$ & 1039 \\
\hline & Yellow & $\mathrm{PbSnO}_{4}$ & $131 / 199 / 454$ & - & 1018 \\
\hline & Green & Naples Yellow & 135 & - & 1018 \\
\hline & & $\mathrm{Cr}_{2} \mathrm{O}_{3}$ & 523 & & \\
\hline & Pink & Hematite & 1585 & - & - \\
\hline \multirow[t]{8}{*}{ G913 } & Yellow & Naples Yellow & 135 & 504 & 1000 \\
\hline & Red & Hematite & $218 / 285 / 1300$ & - & - \\
\hline & Mustard & Hematite & $214 / 277 / 1303$ & - & - \\
\hline & Green & - & - & 481 & 968 \\
\hline & Black & Fe3O4- & 549 & - & 979 \\
\hline & & $\mathrm{Cr}_{2} \mathrm{MnO}_{4}$ & & & \\
\hline & & $\mathrm{CoO}$ & 473 & & \\
\hline & Red Black & Hematite & $218 / 281 / 1290$ & - & - \\
\hline \multirow[t]{4}{*}{ G5068 } & Yellow & Naples Yellow & 140 & 454 & 1041 \\
\hline & Green & - & - & 496 & 979 \\
\hline & Blue & - & - & 485 & 982 \\
\hline & Red & Hematite & $218 / 285 / 1300$ & - & - \\
\hline \multirow[t]{2}{*}{ G421 } & Green & - & - & $462 / 492$ & 996 \\
\hline & Red & Hematite & $226 / 293 / 1314$ & - & - \\
\hline \multirow[t]{6}{*}{ G3361 } & Red & Quartz & 462 & - & - \\
\hline & Green & - & - & 462 & 989 \\
\hline & Blue & $\mathrm{Co}_{2} \mathrm{SiO}_{4}$ & 827 & 466 & 1018 \\
\hline & White & Arsenate & 831 & 466 & 1028 \\
\hline & Purple & $\mathrm{Co}_{2} \mathrm{SiO}_{4}$ & 827 & 477 & 968 \\
\hline & Black & $\mathrm{Fe} 3 \mathrm{O} 4-$ & 542 & 454 & 979 \\
\hline
\end{tabular}


Table S2: Representative mean glaze compositions (after F. Zhang [5] and Kingery \& Vandiver [6])

\begin{tabular}{|c|c|c|c|c|c|c|c|}
\hline Oxide & $\begin{array}{l}\text { Famille } \\
\text { verte } \\
\text { over }\end{array}$ & $\begin{array}{l}\text { Famille } \\
\text { verte } \\
\text { over }\end{array}$ & $\begin{array}{l}\text { Famille } \\
\text { rose } \\
\text { over }\end{array}$ & $\begin{array}{l}\text { Famille } \\
\text { rose } \\
\text { over }\end{array}$ & $\begin{array}{l}\text { Famille } \\
\text { rose } \\
\text { over }\end{array}$ & $\begin{array}{l}\text { Famille } \\
\text { rose } \\
\text { over }\end{array}$ & $\begin{array}{l}\text { Famille } \\
\text { rose } \\
\text { over }\end{array}$ \\
\hline colour & blue & green & blue & rose & white & yellow & black \\
\hline $\mathrm{SiO}_{2}$ & 42.1 & 29.0 & 45.2 & 45.1 & 43.3 & 35.2 & 29.6 \\
\hline $\mathrm{Al}_{2} \mathrm{O}_{3}$ & 0.4 & 0.6 & 0.7 & 0.6 & 1 & 0.3 & 1.5 \\
\hline $\mathrm{CaO}$ & 0.9 & 0.15 & 0.35 & 0.3 & 0.15 & 0.8 & 0.1 \\
\hline $\mathrm{MgO}$ & 0.05 & 0.02 & 0.1 & 0.1 & 0.1 & 0.1 & 0 \\
\hline $\mathrm{K}_{2} \mathrm{O}$ & 6.2 & 0.2 & 5.8 & 2.1 & 5.7 & 2.75 & 0.14 \\
\hline $\mathrm{Na}_{2} \mathrm{O}$ & 0.4 & 0.1 & 2.7 & 2.75 & 2 & 1.4 & 0.25 \\
\hline $\mathrm{FeO} / \mathrm{Fe}_{2} \mathrm{O}_{3}$ & 0.3 & 1.15 & 0.5 & 0.15 & 0.2 & 0.4 & 0.2 \\
\hline $\mathrm{TiO}_{2}$ & $\sim 0$ & 0.02 & - & - & - & - & \\
\hline $\mathrm{P}_{2} \mathrm{O}_{5}$ & 0.02 & $\sim 0$ & - & - & - & - & \\
\hline PbO & 47.8 & 66.2 & 38.4 & 47.3 & 43.2 & 57.5 & 67.1 \\
\hline $\mathrm{CoO}$ & 0.2 & & 0.30 .1 & & & & 0.25 \\
\hline $\mathrm{CuO}$ & & 6 & & & & & 0.05 \\
\hline $\mathrm{SnO}_{2}$ & 0.3 & & - & 0.2 & 0.1 & 2 & - \\
\hline $\mathrm{As}_{2} \mathrm{O}_{5}$ & & & 1.4 & $\mathbf{0}$ & 4.3 & & $\mathbf{0}$ \\
\hline $\mathrm{Au}$ & & & & 0.1 & & & - \\
\hline $\mathrm{MnO}_{2}$ & & & & & 0.03 & & 0.5 \\
\hline
\end{tabular}

Actually, pottery glaze composition varies from the body glaze interface to the glaze surface; -: not determined. 


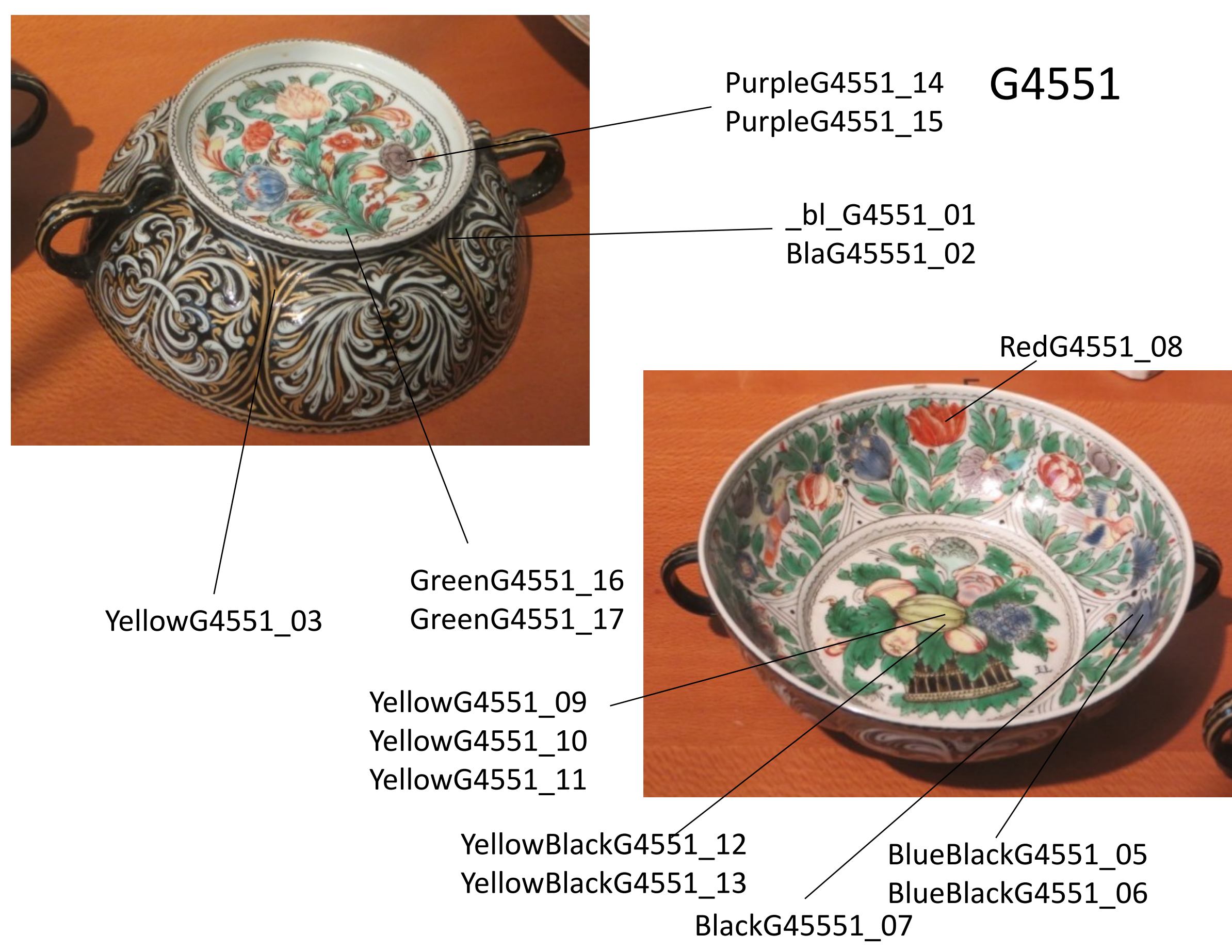


G5250

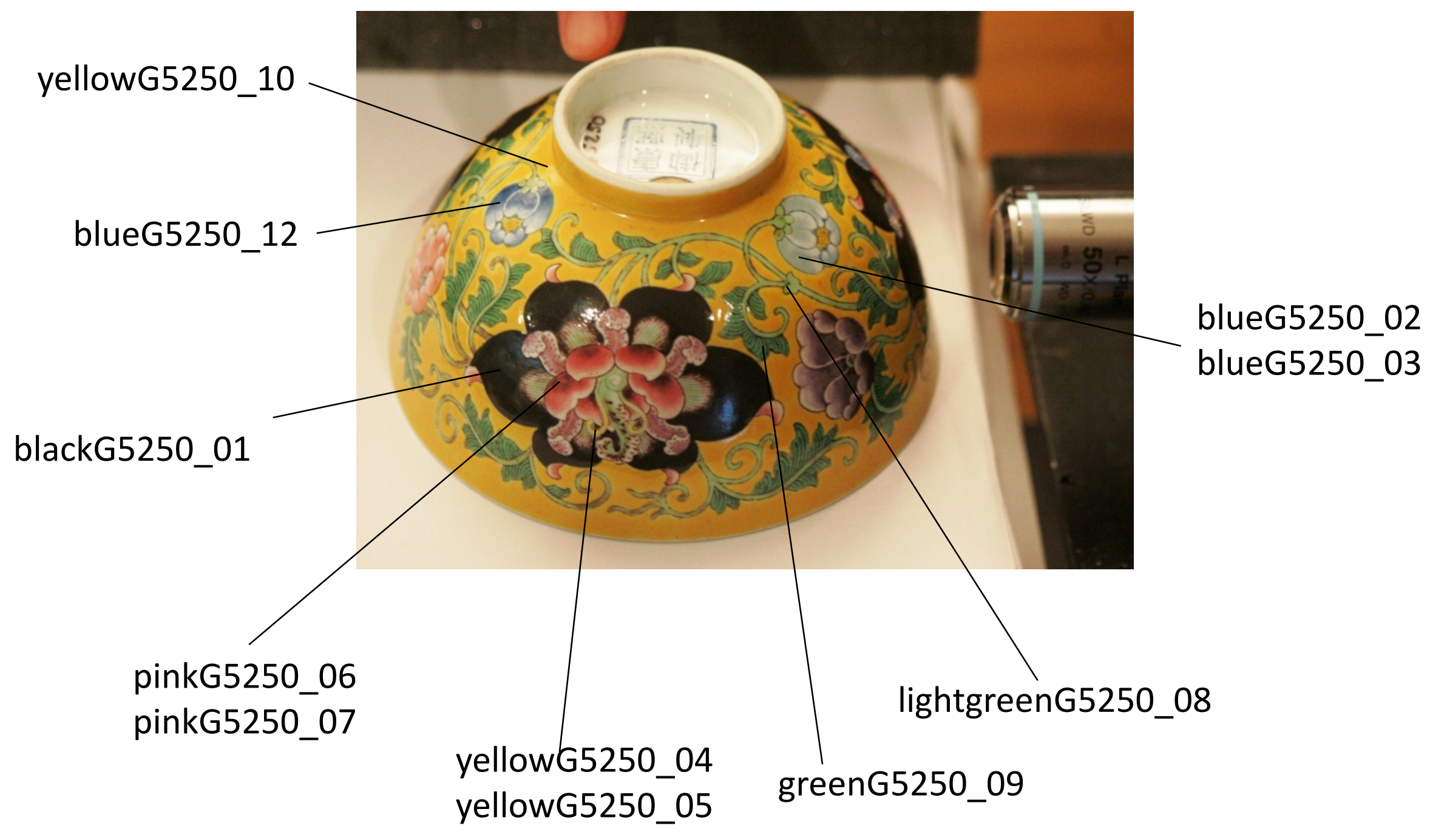


G4806

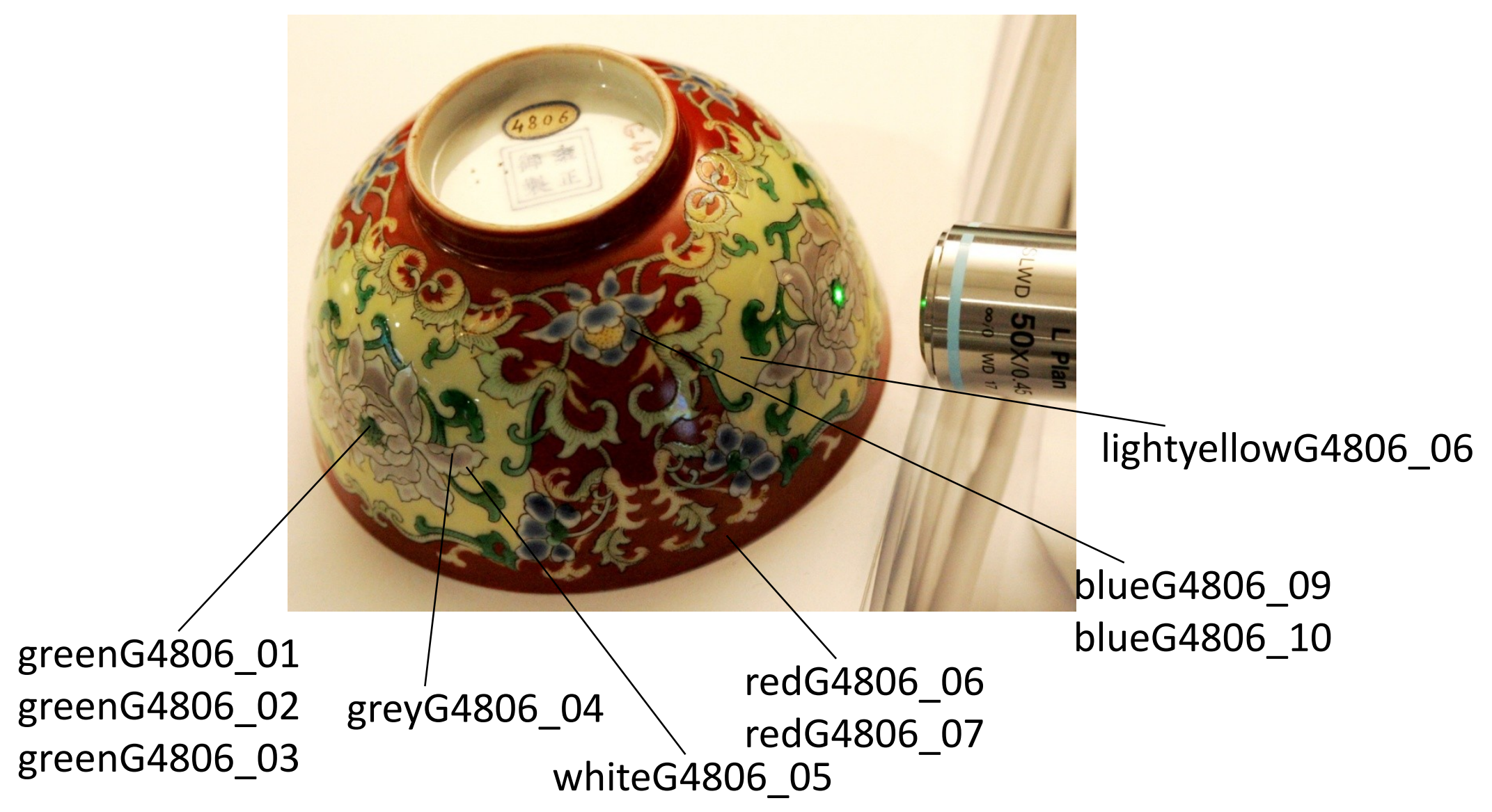


G913

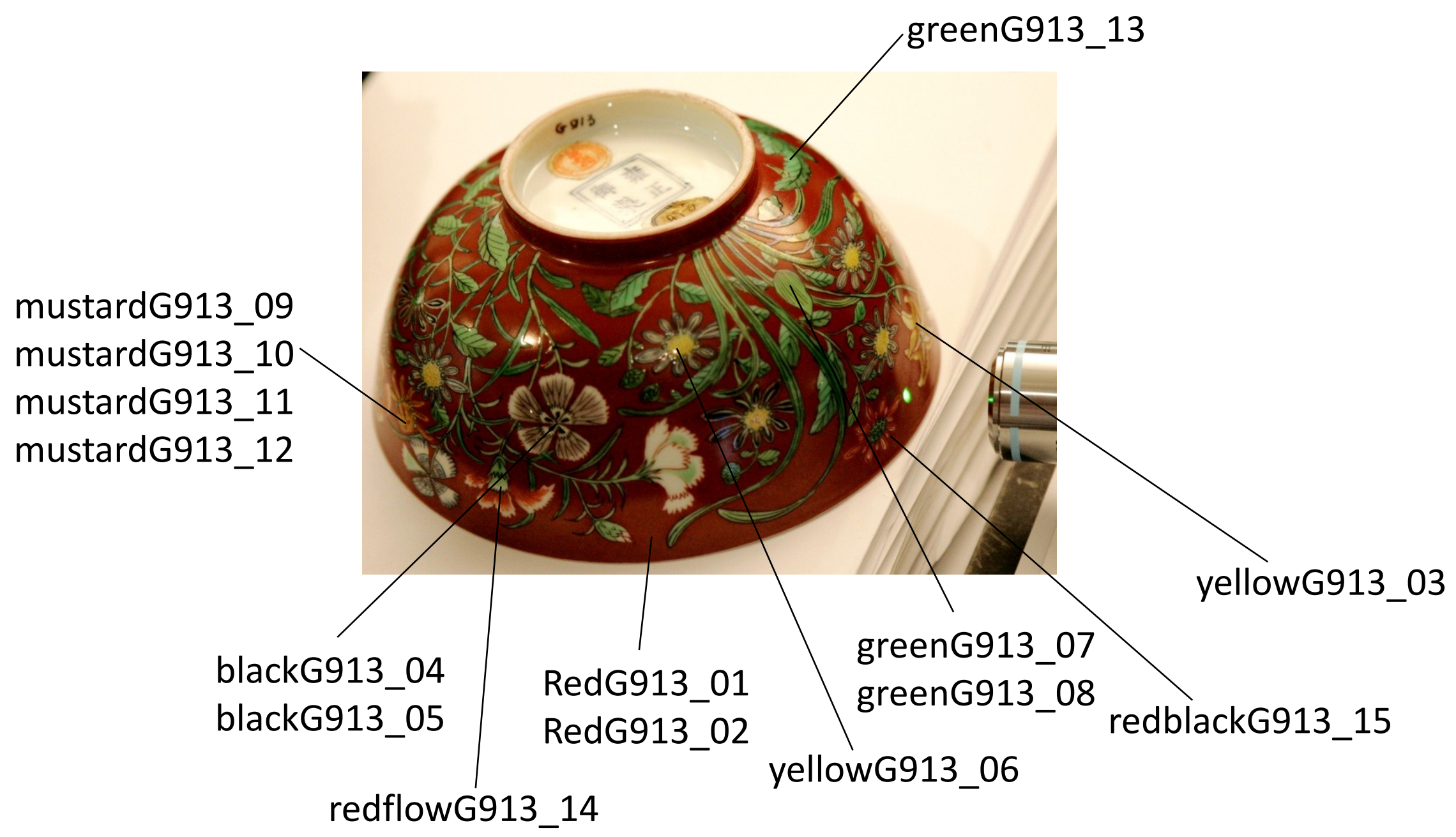




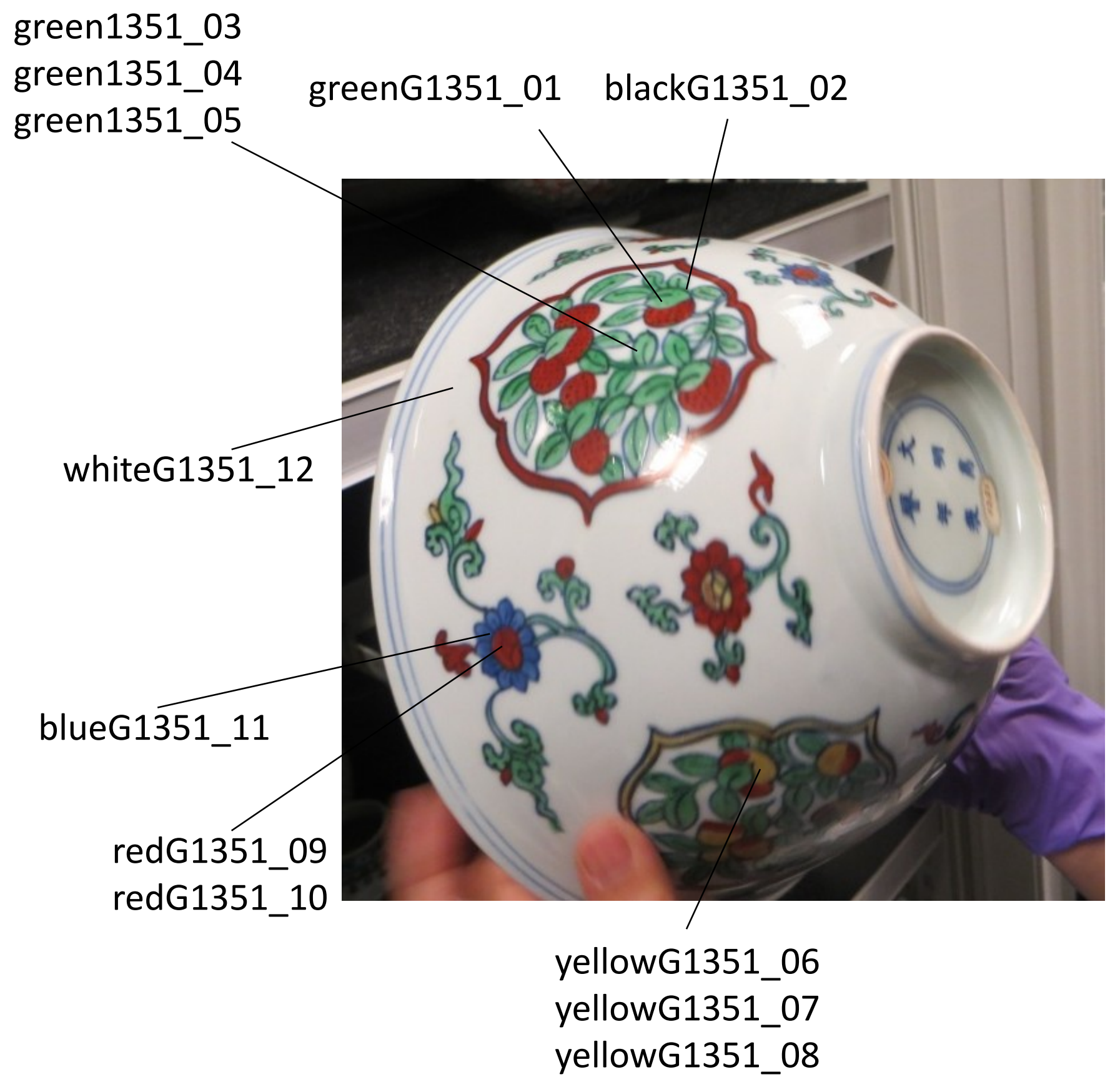

G1351 
G421

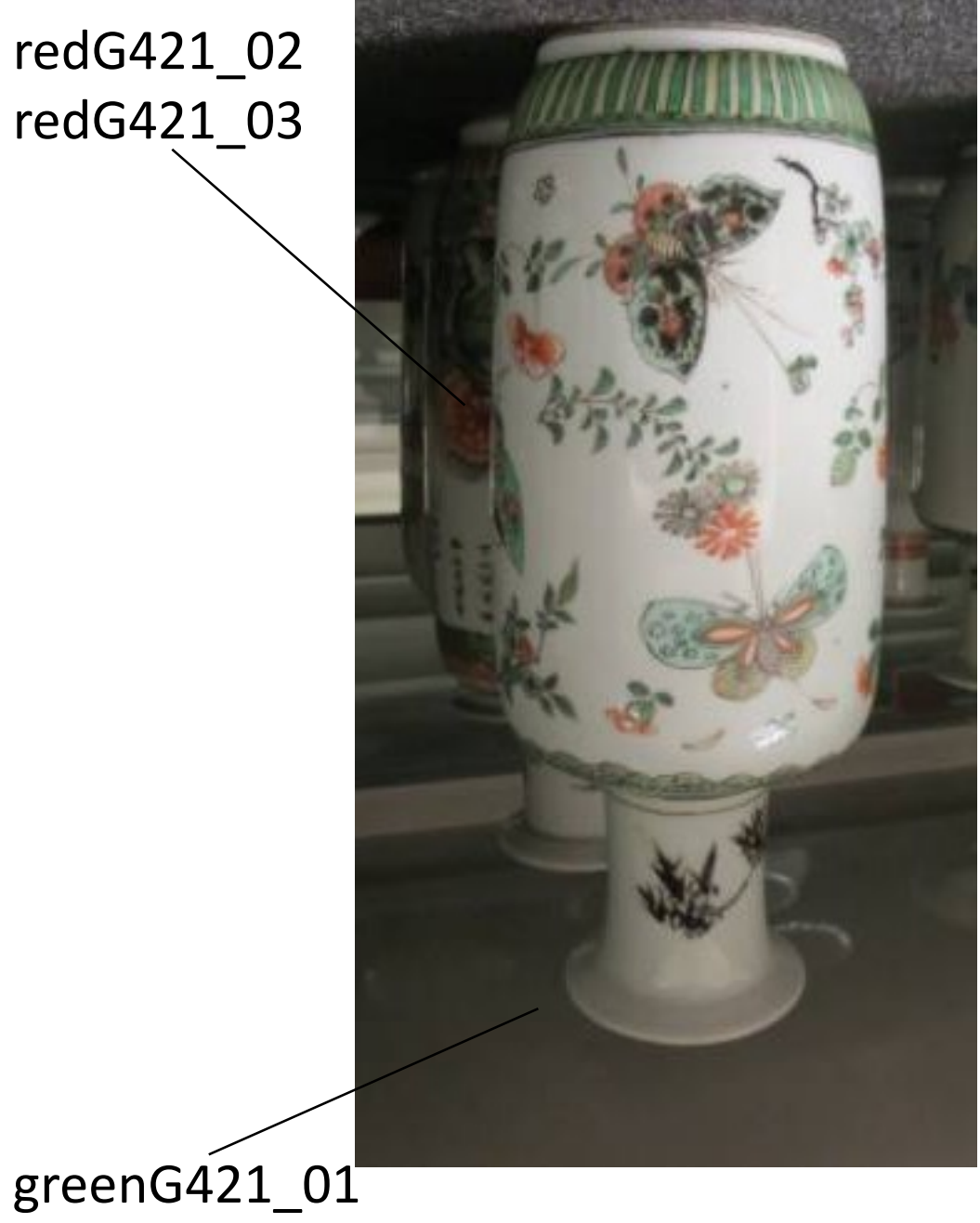




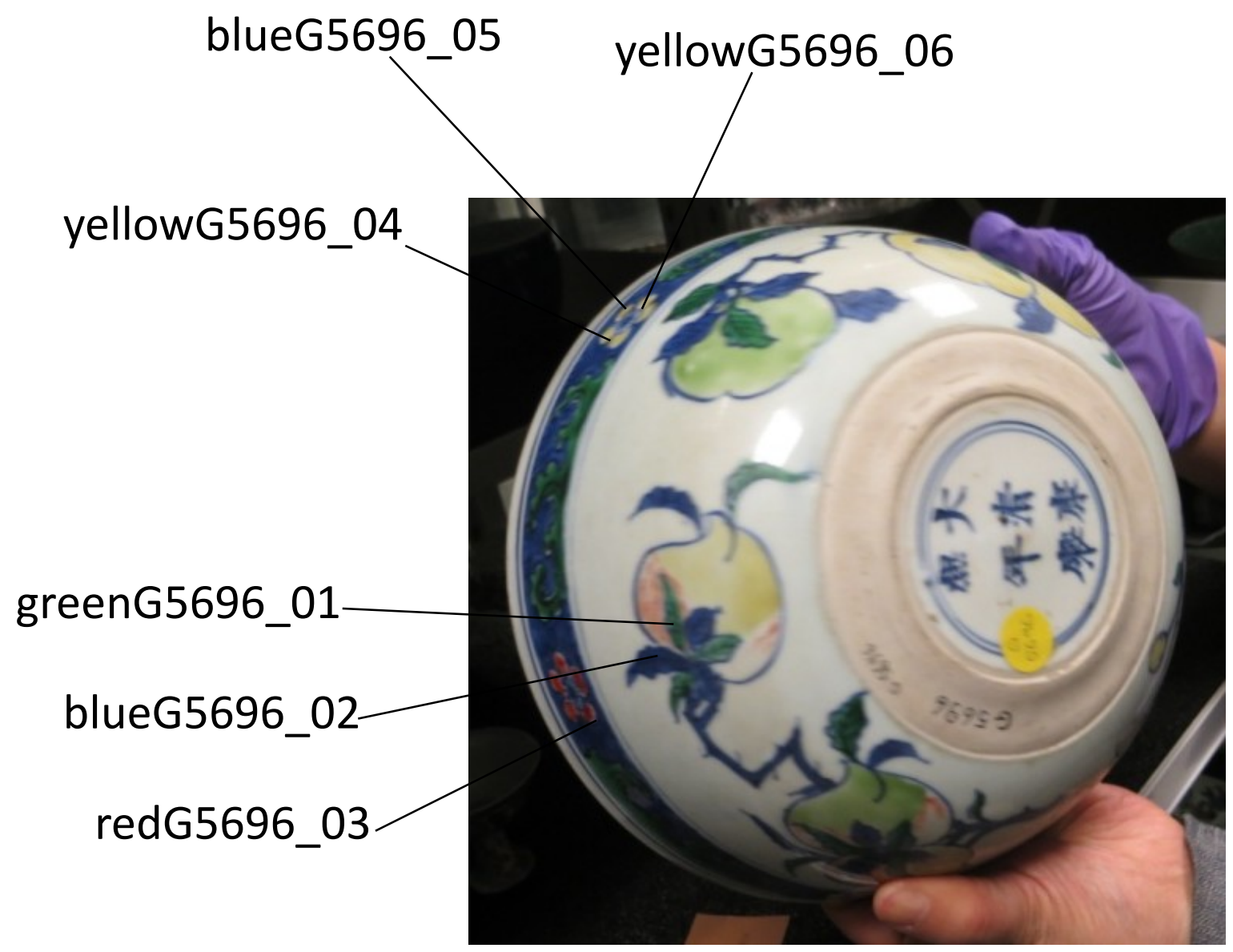

G5696 


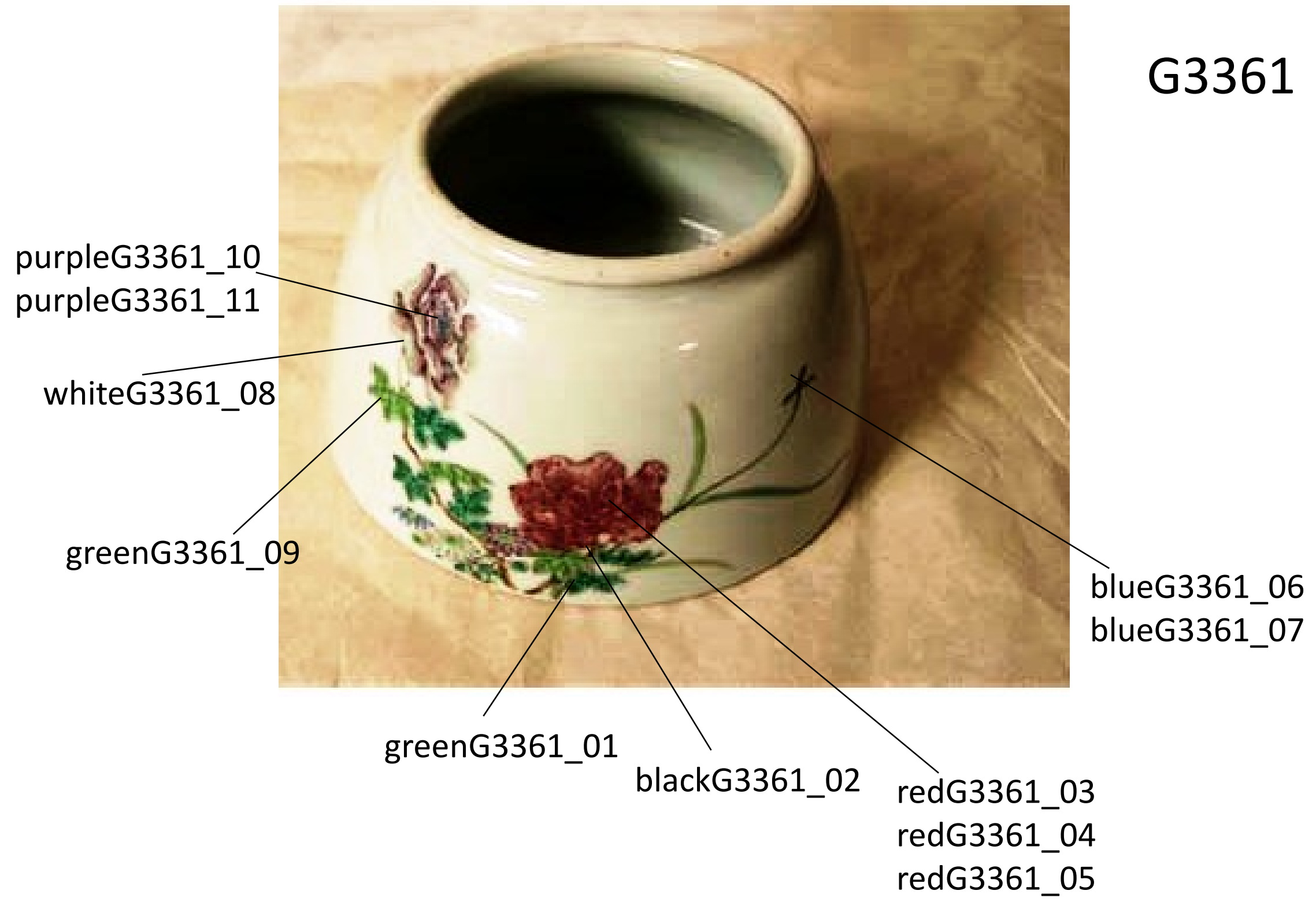




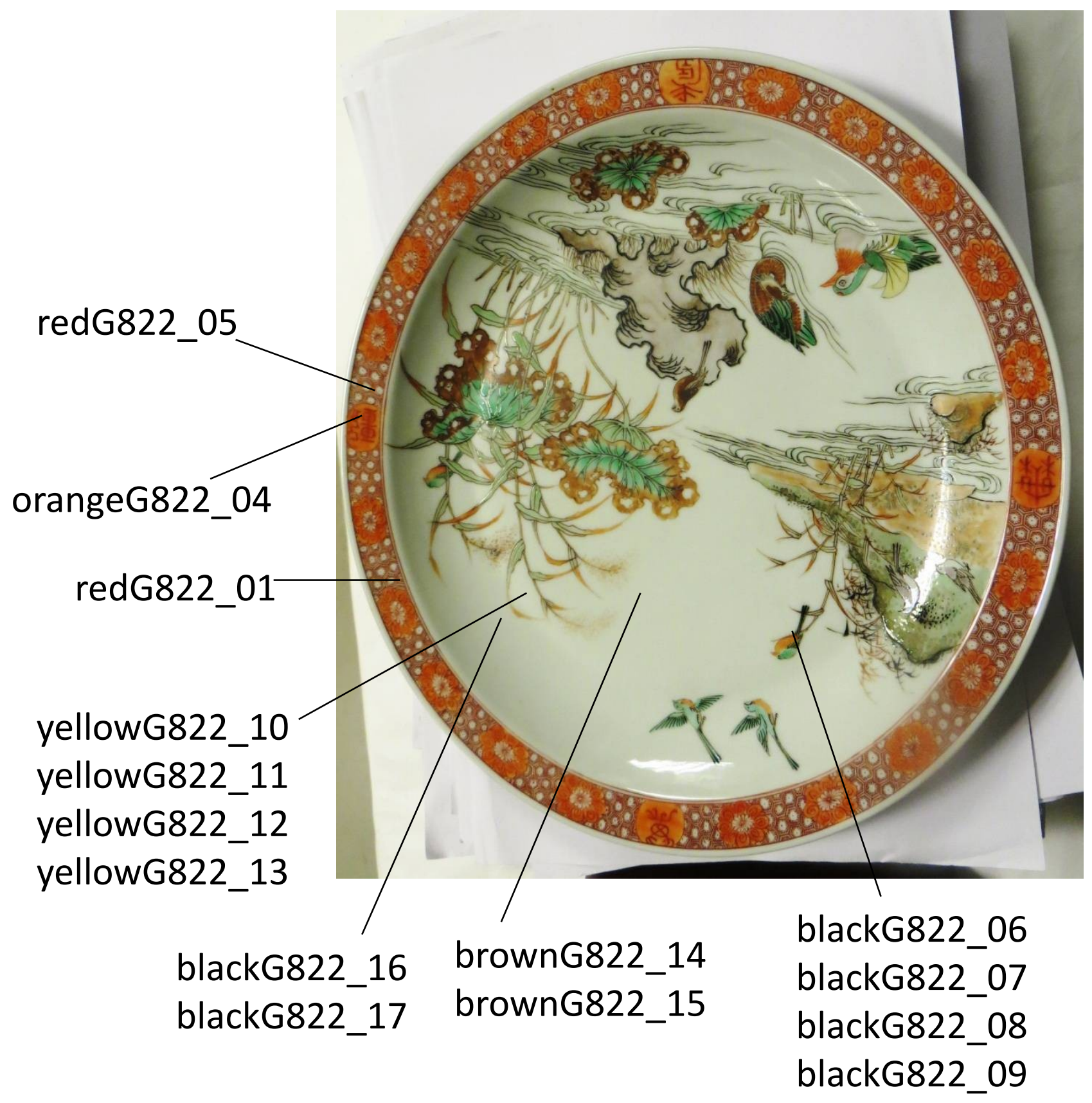

G822 


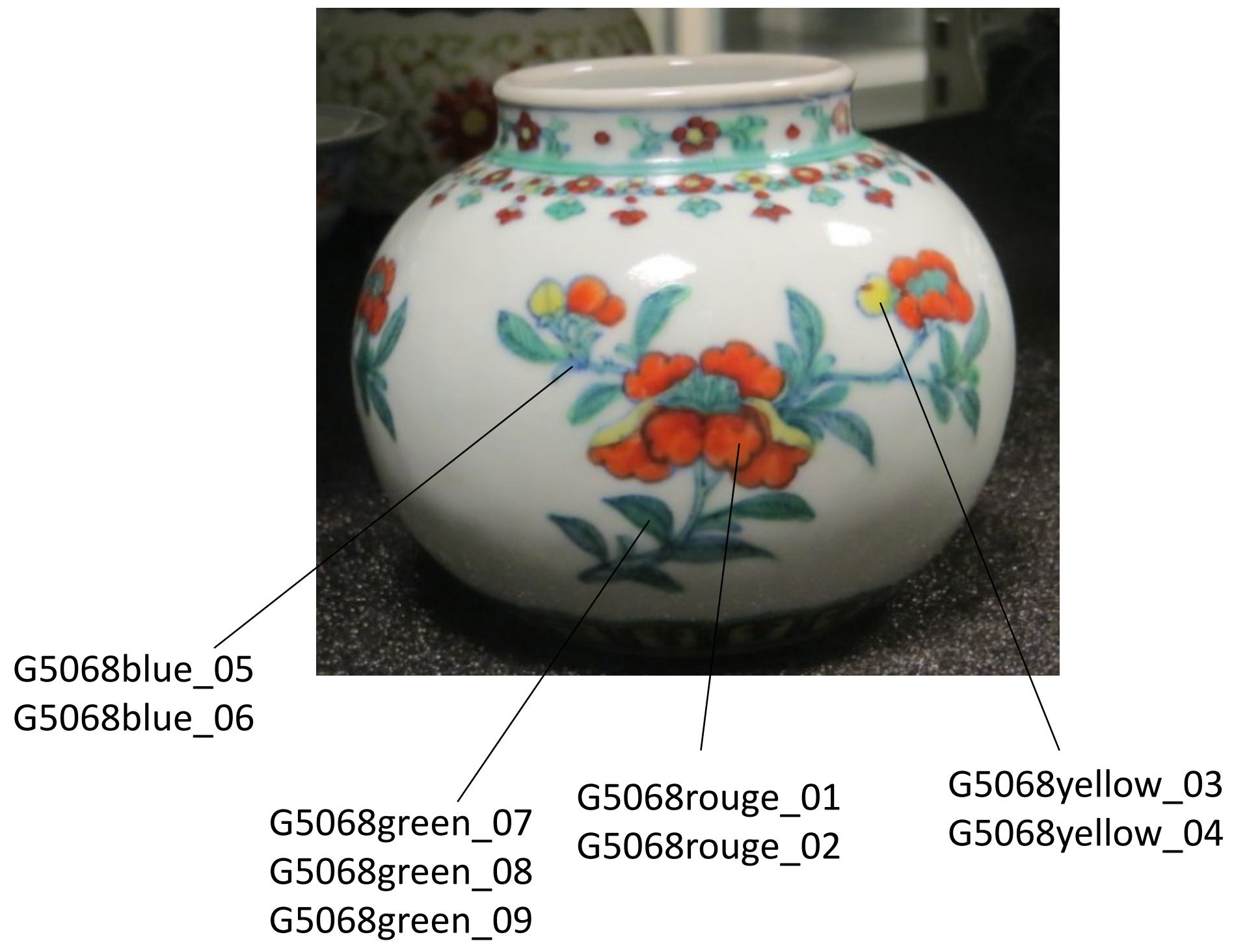




\section{G4611}

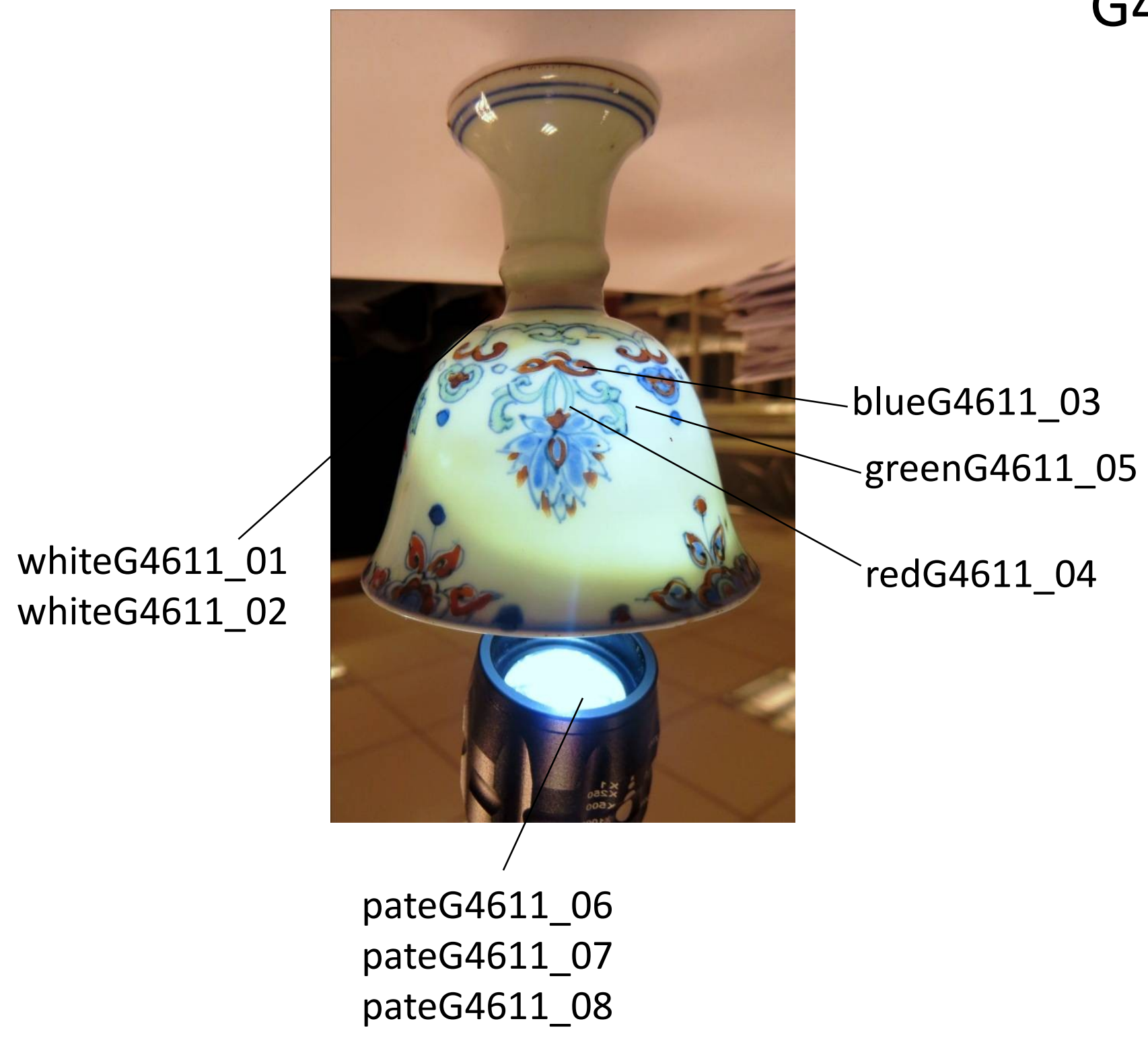


Va1710yelflower_01 Va1710yelflower_02

Va1710yelflower_03

Va1710yelflower_04

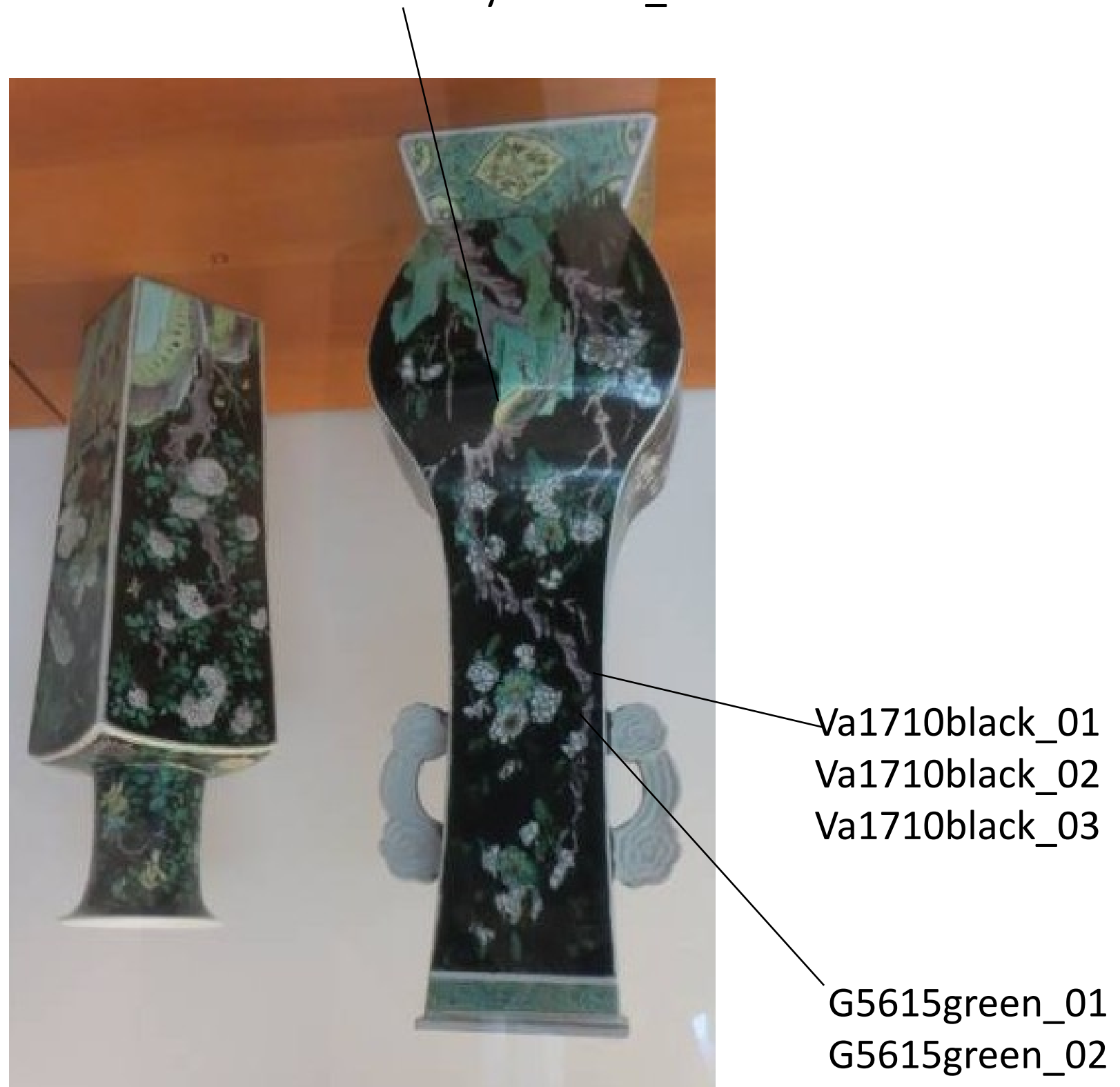


G5615

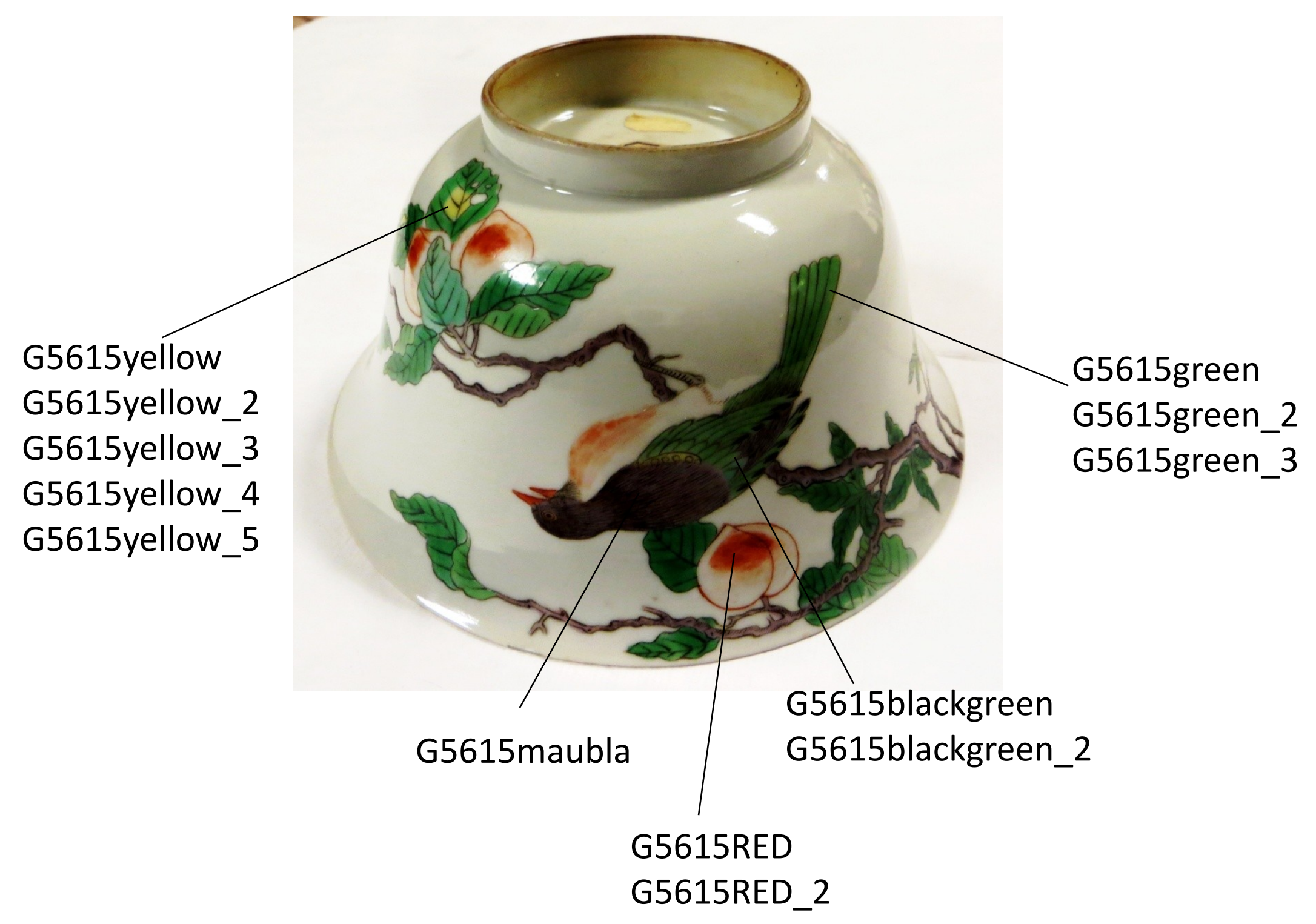




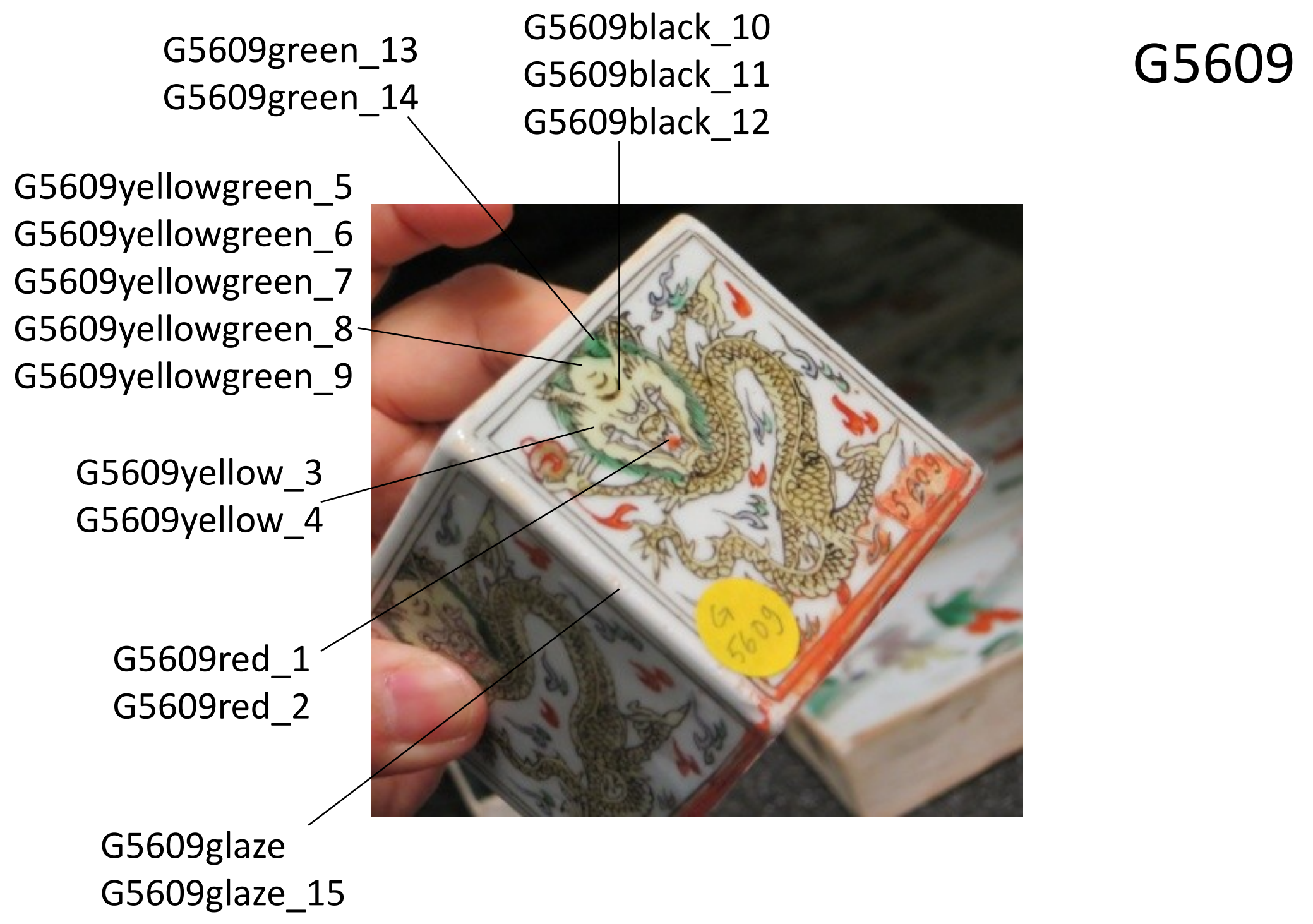




\section{MG3668}

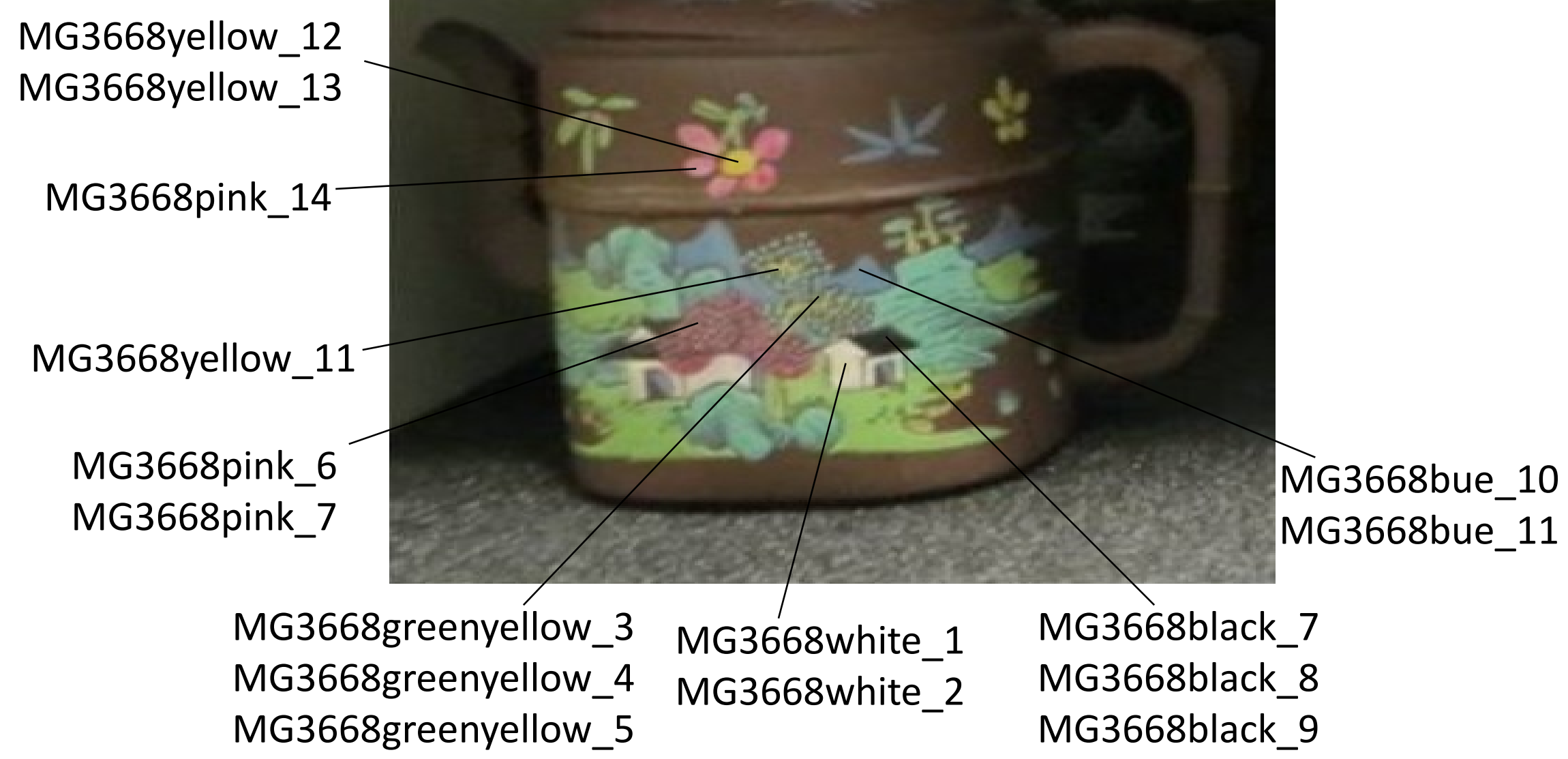




\section{MG9604}

YxMG9604darkblue_11 YxMG9604darkblue_12

YxMG9604white_10 YxMG9604blue_9

YxMG9604yellow_3 YxMG9604white-yellow_4 YxMG9604white-yellow_5 YxMG9604black_13 YxMG9604green_2 YXMG9604black_14 YxMG9604black_15 
MG8062

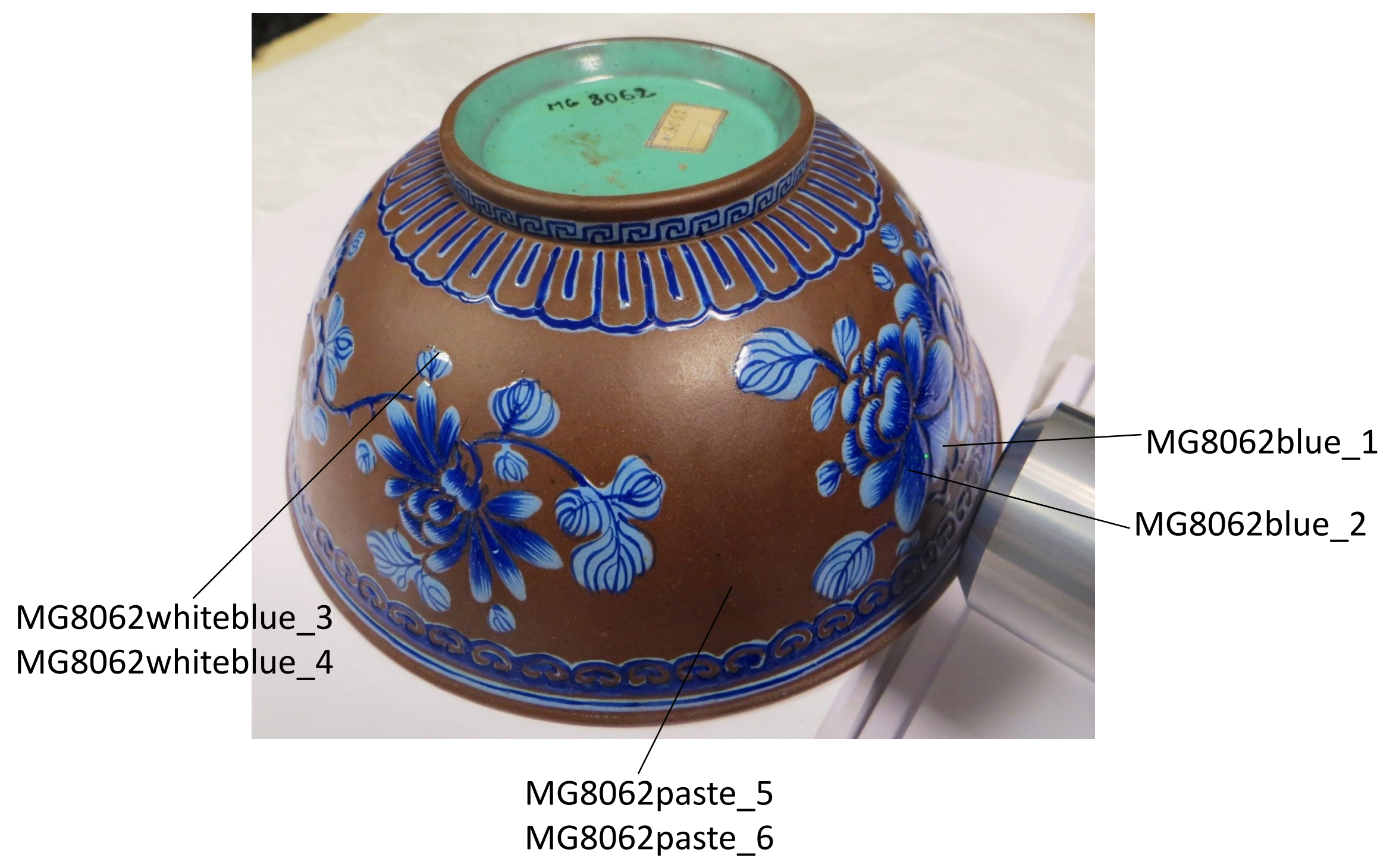




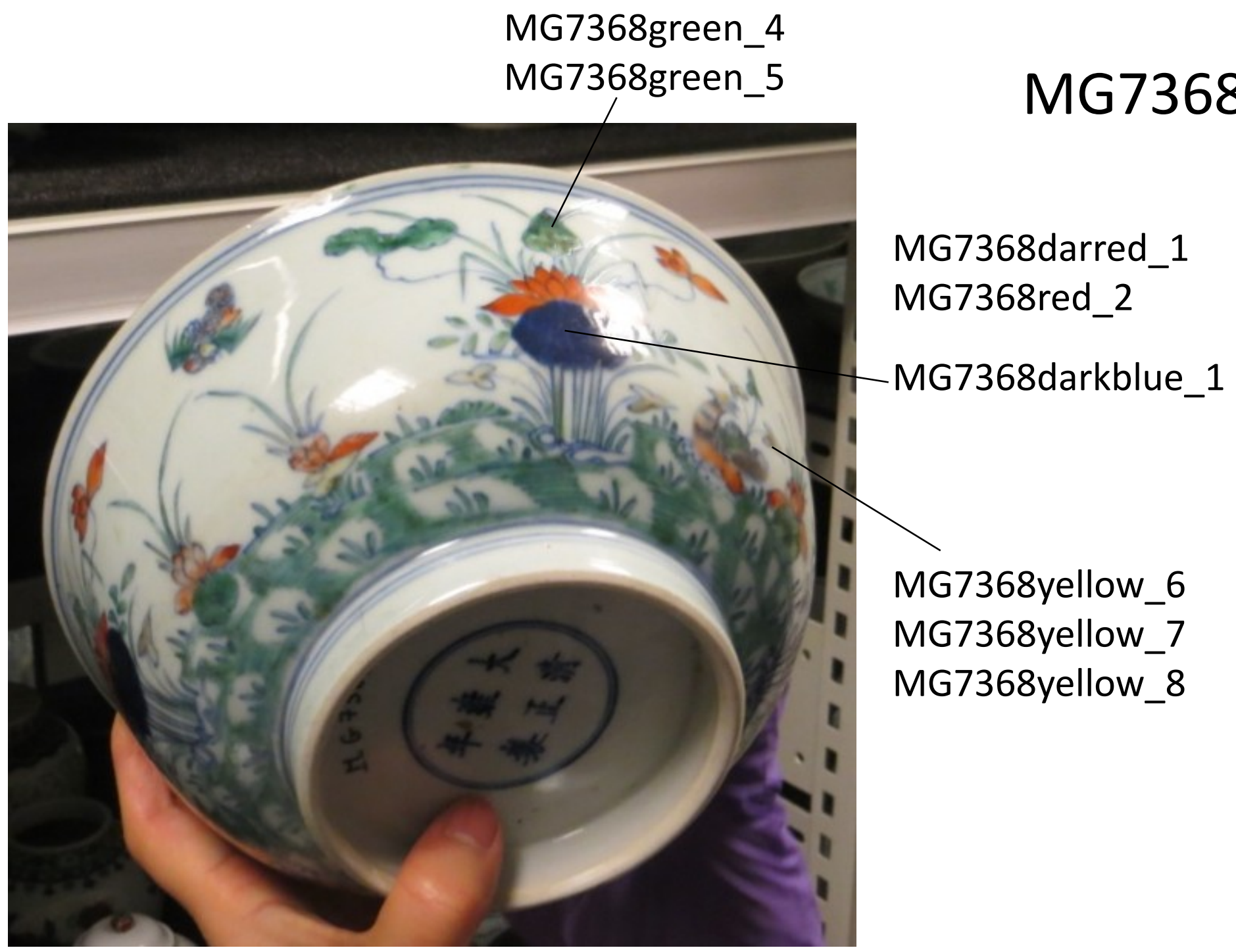




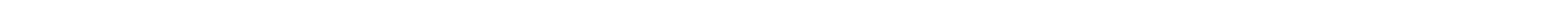




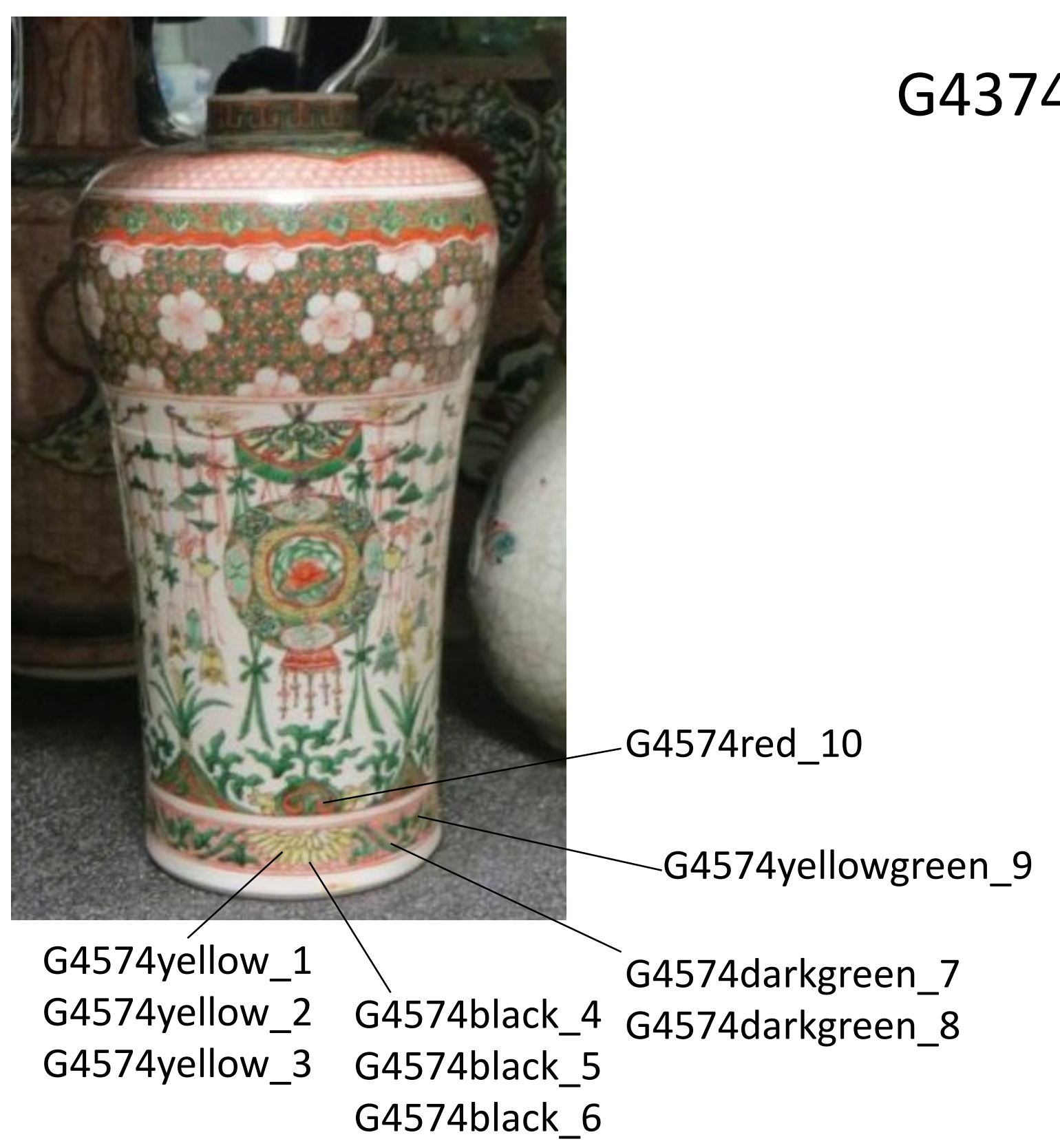




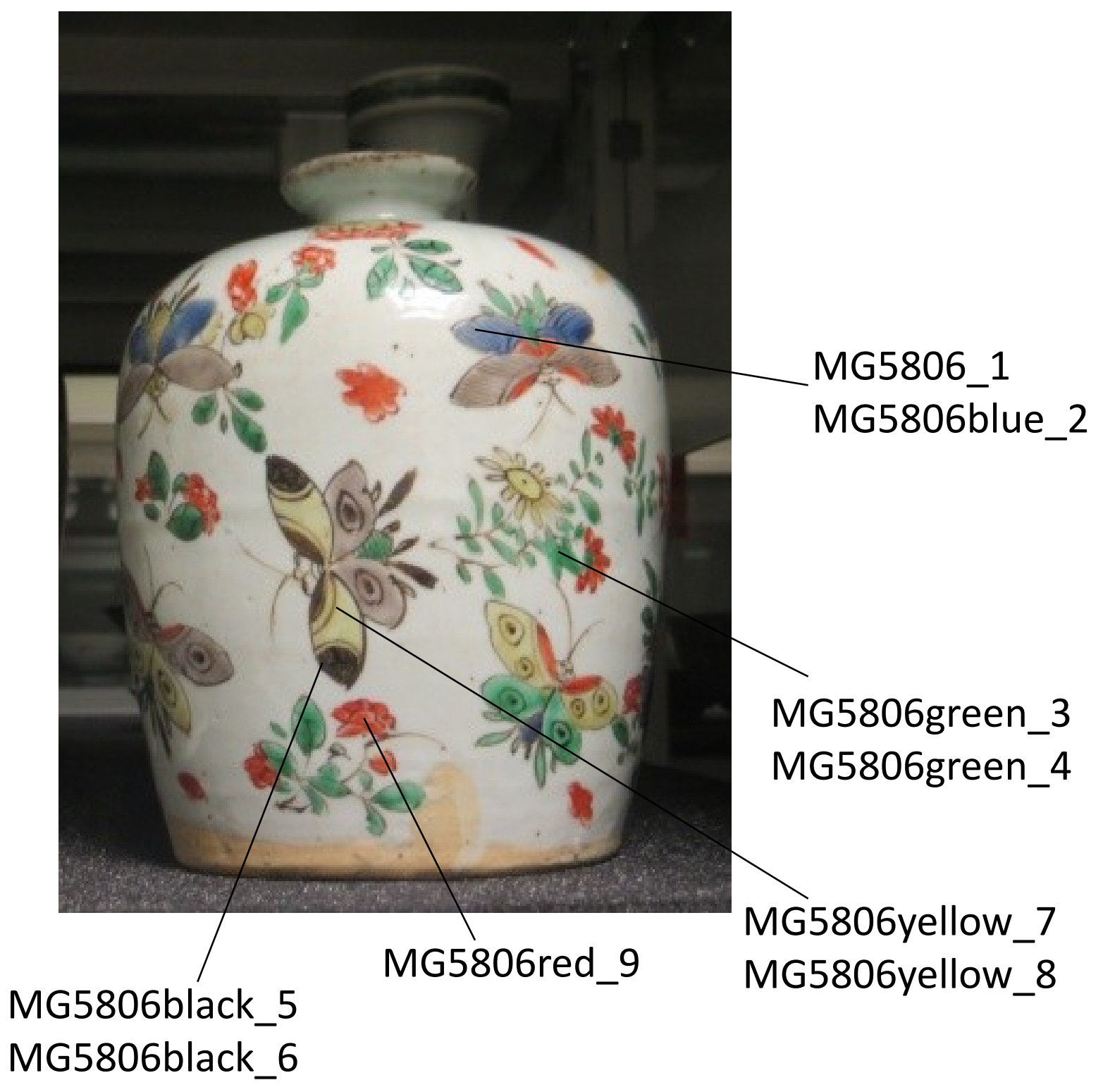

